R E V I E W

D R A F T

\title{
DIRECT USE OVERVIEW \\ FOR HAWAII \\ AND TOTAL USE SCENARIO \\ FOR PUNA (HI)
}

12. January 1979

Prepared for:

U.S. DEPARTMENT OF ENERGY

Onder Contract

ET-78-C-03-1529

\section{Prepared by :}

Sclence Applications, Inc. 1200 Prospect Street

La Jolla, California 92038 


\section{DISCLAIMER}

This report was prepared as an account of work sponsored by an agency of the United States Government. Neither the United States Government nor any agency Thereof, nor any of their employees, makes any warranty, express or implied, or assumes any legal liability or responsibility for the accuracy, completeness, or usefulness of any information, apparatus, product, or process disclosed, or represents that its use would not infringe privately owned rights. Reference herein to any specific commercial product, process, or service by trade name, trademark, manufacturer, or otherwise does not necessarily constitute or imply its endorsement, recommendation, or favoring by the United States Government or any agency thereof. The views and opinions of authors expressed herein do not necessarily state or reflect those of the United States Government or any agency thereof. 


\section{DISCLAIMER}

Portions of this document may be illegible in electronic image products. Images are produced from the best available original document. 
As a means of accelerating the environmentally acceptable use of geothermal resources in the state of Hawail, this report presents an overview of the potential for direct utilization (non-electric) in the state and a scenario for development to the year 2020 of the most promising prospect - Puna, on the Big Island of Hawaii.

\section{Direct Dse Overview}

Potential resource prospects were identified, then matched with appropriate uses which were suitably located to adapt to geothermal use. The resource prospects were identified based upon limited temperature and silica indicators and proximity to geologic structures. Fourteen moderate and high temperature geothermal prospects were identified. Prospects on the Big Island of Hawaij and the more developed island of Oahu were identified as the most promising, including Kawaihae, Hilo, and Pina on the Big Island, and Makaha, Lualualei, and Waimanalo on Oahu. Other prospects on Maui and Kauai were identified.

Since co-location of resource and applications is essential to development, existing industrial and commercial business operations and potential residential applications were identified and located to determine viable prospect-user pairs.

Potential direct heat applications in the state include:
- Sugar Refining
- Aquaculture Farms
- Fermentation and Distillation
- Preezing
- Drying 


\section{- Canning}

- Light Industrial Applications

- Manganese Nodule Processing

- Aluminum Manufacturing

- Production of Hydrogen

- Air Conditioning

- Hot Spring Spas

Of the possible potential direct uses, tro major viable prospect-user pairs vere identifled: sugar mills and aquaculture farms. Both industries are important to the Hawailan economy and both are large users of process heat. The resort industry was also identified as having significant potential for utilization of medium grade resources for space conditioning, bealth spas, and water and swimming pool heating. An economic analysis of one hypothetical industrial user at Keaau, on the B1g Island showed a cost of process heat of between $\$ 1.30$ and $\$ 2.18$ per million BTU's. This compared very favorably with oil at $\$ 2.50$ per million BTU.

Total Use Scenario - Puna

Puna, on the Big Island of Hawail, was selected as the site for development of an integrated (electric and direct use) scenario. Puna is the site of one of the hottest geothermal vells in the world and has near-term prospects for development, including the ongoing wellhead-generator program, a possible direct use application with the puna Sugar Company, and recentlygenerated interest in producing a $20 \mathrm{uII}$ power plant (the Tokyu Land Development Company and GEDCO both are giving consideration to development if adequate financing becomes available). The purpose of the scenario is to trace the commercialization of geothermal resources from 1979 to 2020. The vellhead-generator $\mathbf{w i l}$ be on-line in 1981, the direct use process could be opera- 
$=$ ate 1982, and the power plant could be on-line in - idition to vear-term development, industrial develop$=$ aergy-intensive industrial operations, including male and aluminum reduction facilities, is considered Flation of the scenario. Near-term development is = zuse existing utility facjities are adequate to serve $\therefore$ market. Development in the long-term will be E on an influx of more energy-intensive industry.

:be near-term, several impediments to commerciali$=-\infty$ identified. These include native rights, resource was, regulatory requirements, the limited demand for $\because$ ina, incomplete researcb and development, and znergy sources.

result of the Direct Use Overview and Puna Total I:- = the following programmatic needs were identified:

iurther resource exploration and exploratory : rilling should be encouraged by the Federal, State .nd County Governments with researcb support, egulatory streamining support, and financial zcentives. Dnless these measures occur in the very iear term much of the momentum toward development is be lost.

I economic and marketing analysis of the potential zes of the resource, emphasizing energy-intensive zdustrial processes, should be performed.

ix and relocation incentives may be necessary. In Idition, support for local governments may be seded to provide the infrastructure and services squired for rapid development.

irification of conflicts between state and private mership of the resource is required.

jarification of native claims issues is required.

Fis no question that a potentinlly very sisjificant gec: ance exists in the state of Hawail, or that its ut: - ald significantly enbance the-state's energy 
independence, provided a bold and timely commitment is made to support this industry. 
Executive Sumary • . . . . . . . . . . . . I

Table of Contents.................. . . v

Tables . . . . . . . . . . . . . . . . . vi

Figures . . . . . . . . . . . . . . . . vii

Photograph, The Puna Site - BCP-A. . . . . . Viii

1.0 Introduction . . . . . . . . . . . . . . . . 1

1.1 Direct Use Overview of Geothermal Resources for the State of Hawail........... 1

1.2 Puna Integrated Scenario . . . . . . . . 2

2.0 Potential Geothermal Resources . . . . . . . 6

2.1 Potential Geothermal Prospect Locations . . 6

2.2 Depth of Prospects . . . . . . . . . . 10

2.3 Results.................. 10

3.0 Potential Direct Use Application in Hawail. . . 12

3.1 Potential Users............... . 12

3.2 Sugar kills................. 16

3.3 Aquaculture Farms . . . . . . . . . . . 17

3.4 Economics of Geothermal Direct Heat
Application in Hawaii........... 21

3.5 Findings and Recommendations ....... 23

4.0 Puna Integrated Scenario . . . . . . . . . . 29

4.1 Puna Near-Term Commercialization 39

4.2 Power Demand Potential .......... . 36

4.3 Impediments to Comercialization ..... 37

4.3.1 Resource Ownership . . . . . . . 37

4.3.2 Hawailan Native Claims. . . . . . 38

4.3.3 Regulatory Requirements...... 38

4.3.4 Limited Demand for Energy in Puna. 39

4.3.5 Ongoing Researcb and Development : 39

4.3.6 Competitive Energy Sources . . . . 39

4.4 Puna Integrated Scenario (1979-2020) . . . 40

4.5 Recomediations.............. 45

Beferences. . . . . . . . . . . . . . . . 47

Sppendix A Geological structure Maps and Resource Indicators for the Hawailan Islands . . . . . 48

Appendix B Potential Dsers and Resources in the Hawailan 


\section{TABLES}

Table 1 Probable Prospect Locations . . . . . . . . . $\frac{\text { Page }}{8}$

Table 2 Wells $>25^{\circ} \mathrm{C}$ and Depth Below Sea

Level from HIG Progress Report \#2 . . . . . . . 11

Table 3 Hawai's Potential Users of Direct

Heat (Existing)................. 13

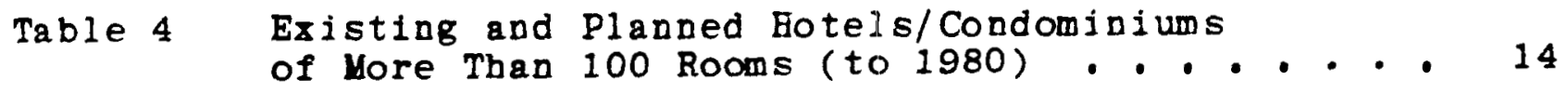

$\begin{array}{ll}\text { Table } 5 & \text { Temperature Ranges of Several Different } \\ \text { Aquaculture Species . . . . . . . . . . . . . } 19\end{array}$

$\begin{array}{ll}\text { Table } 6 & \text { Aquaculture Potential Adjacent to Fotential } \\ \text { Geothermal Resource Areas . . . . . . . . . } 20\end{array}$

$\begin{array}{ll}\text { Table } 7 & \text { Economic Parameters for Hypothetical Keaau } \\ & \text { Direct Beat Application . . . . . . . . . } 22\end{array}$ 


\section{FIGURIS}

$\underline{\text { Page }}$

Figure 1 Geothermal Prospect Areas in the State

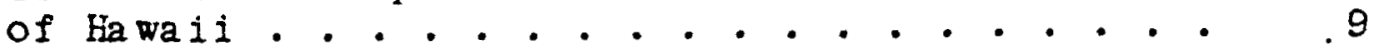

Figure 2 Eotel, Condominium, and Major Urban Areas in the State of Hawaii . . . . . . . . . 25

Figure 3 Industrial Locations in the State of Ha waii... . . . . . . . . . . . 26

Figure 4 Temperature and Silica Indicators in the State of Hawaii..............

Figure 5 Rift zones and Calderas in the State of Hawaii... . . . . . . . . . . . .

Figure 6 Puna Wellhead Generator, Direct Use, and $20 \mathrm{MW}$ Plant Scenario . . . . . . . . 33

Figure 7 Cverview - Puna Integrated . . . . . . . . Scenario - Geotbermal Energy Commercialization 


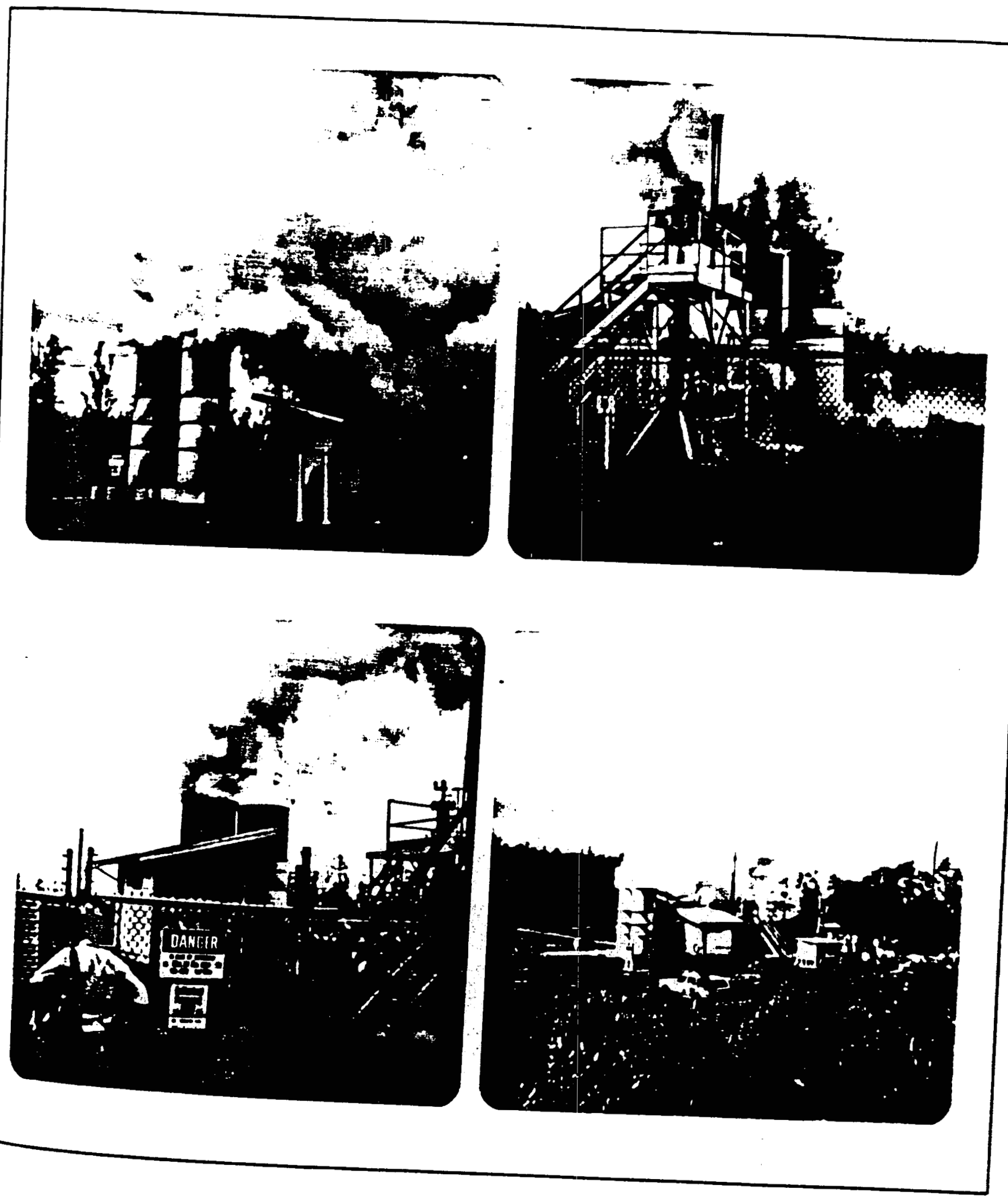

THE PUNA SITE - HGP-A 


\subsection{INTRODUCTION}

In response to the Department of Energy Contract No. ET-78-C-03-1529, "Regional Operations Research for Geothermal Energy Resources in California and Hawail," this report contains an overview of the cirect utilization of geothermal energy for Hawaii and an integrated scenario of the Puna prospect. Pacific Analysis Corporation and Action Resources, Inc. performed much of the work in this presentation under subcontract to science Applications, Inc.

1.1 DIRECT USE OVERVIET OF GEOTHERMAL RESOURCES FOR THE STATE OF HATAII

The purpose of the direct use overview for Hawail is to locate geothermal resources capable of sustaining direct use applications and to Identify potential users. Users selected include cane sugar milis, aquaculture farms, and large resort complexes. Geothermal energy must be utilized near where it is extracted; it is essential to 1dentify areas in which both the resource and the users are present.

The overview is organized according to the following subtasks :

- Inventory geothermal resources exhibiting potential for direct-use applications.

- Analyze potential direct use applications based on real-world constraints borne by potential users, including new industries.

- Analyze the technological, economic and environmental aspects of the above subtasks.

Due to extreme time constrints and litited available funding, certain limitations have been observed. Data on potential resource locations from a single information source 
Industrial activity on the island of Hawail, aside from that associated with sugarcane processing, is minimal. It seems likely that with only moderate incentive to development, geothermal resources can be a source of relatively economical indigenous energy.

A substantial improvement in the economics of the primary cash crop, sugar, and development of aquaculture operations would be possible, given imaginative use of a reliable, abundant energy source. Otber potential uses include processes of fermentation, distillation, freezing, drying, and canning. Other light industrial complexes are also potential candidate uses.

Hot spring spas and other types of recreational destinations for tourism are limited only by imagination; academic and professional retreats have been proposed for many years, scientific research complexes, and even a major East-West business center are only some of the possibilities.

In the longer term, the development of heary industries in Hawail may also prove to be a viable prospect. Mineral processing especially seems to hold potential, due to possible synergisms of raw materials and abundant power and heat from geothermal energy. Considerable interest has been generated in Hawail in the possibility that the cheap heat and electricity available from geothermal energy might make Hawail a site for processing manganese nodules recovered by deep ocean mining in the central Pacific. Dnfortunately, the uncertain state of the deep ocean mining industry at present has taken some of the luster off this idea. A similar possibility would be the manufacture of aluminum from bauxite. Since Australica supplies wuch of the world's bauxite, Hawall would not be an unreasonable processing site for aluminum to be consumed in the Americas. sluminum is generally refined from bauxite using electricity wich could be supplied geothermal1y. From the point of vier of 
capital outlays. Existing governmental structure will have to be a umented significantig to fulfill its responsibilities for planning and supportive developments necessary for large-scale economic development, and if development is to be rapid and non-destructive, it may be necessary to provide small local governments with external support until increased local tax revenues are avallable.

The questions of environmental, social and political stress are, of course, a major concern when considering such rapid growth. Therefore, all planning and implementing must be done in the context of the value placed on this relatively pristine setting by its residents. It is predictable that a large and influential segment of the population may object to any project expected to increase local population. These groups will strongly oppose any potential degradation of the purity, beauty, and tranquility of the area. However, an equally adamant sector of the population, also potentially influential and powerful, desires economic growth if it is not destructive of primary environmental values. 


\subsection{POTENTIAL GEOTHERMAL RESOURCES}

The key to the direct use of geothermal energy is finding areas in which resources and users are co-located; unlike other energy forms, geothermal must be used near the areas in which it occurs. This section presents the methodology utilized to pinpoint potential geothermal resources capable of sustaining direct use applications.

\subsection{POTENTIAL GEOTHERMAL PROSPECT LOCATIONS}

Information on the location of potential prospects was derived from published and unpublished data compiled by the Hawaii Institute of Geophysics (HIG) under the National Geothermal Inventory Program ${ }^{(3)}$. This project is compiling detailed hydrographic and geochemical data on possible resources in Hawaii. Only a small portion of that information is used bere for the purpose of determining areas in which resource potential may coincide with concentrations of population or industry. Vater wells and springs having either elevated temperatures or bigh concentrations of dissolved silica (an indication that the water has been in contact with high temperature rocks at some time) are the focus of the HIG effort.

In order to enable us to deal better with the data a crude ranking system was applied. Each well was assigned points es follows:

- varm water ( $\left.25^{\circ} \mathrm{C}\right)$ vell- 2 points

- silica (> 30ppm) - 1 point

- proximity to a favorable geological feature (volcanic caldera or rift zone) - 1 point

and the points totalled for wells in a given area. Areas with a score of 4 or more vere drawn by inspection and given the name of 
a nearby geographical place. Ibviously, the score of an area is critically affected by the amount of drilling that has taken place in the area, so these totals in no way reflect the likely quality that resources there may have. But since an area with several wells with favorable lndications is a more positive indicator than if there were only a single well, the score may reflect the confidence we should feel in regarding an area as baving a prospective geothermal resource of some kind. By dividing by the number of wells per area we can obtain an idea of how good the indications in an area are per well.

Table 1 presents the areas regarded as prospect areas. Figure 1 shows these areas on a map. Section 3.0 presents similar maps showing concentrations of potential users. The significant point is that several of the high scoring prospects are close to concentrations of users. Bowever, one should not attempt to force any further conclusions from the limited data available. No decisions regarding exploration or other resource work in any area should be attempted whout detailed examination of all the relevant geochemical and geological data (such as the completed HIG reports) by experts familiar with the area.

Limitations arose in utilizing the resulting plots of prospect locations, since (1) the resolution sizes and scales of maps from which the resultant plots were obtained differed and (2) silica indicators were not considered in ranking locations on Baui because the significant rainfall and subsequent subterranean weathering occurring on the 1sland affects the accuracy of the indicator $(3)$. Although questions are raised concerning the silica indicator in areas of high flow rates of fresh water, similar open questions exist for the island of Oabu where an unexplained higher-than-average silica content exists. These situations place a linitation on the results using silica input data. Bowever, continued data collection and interpretation by 
the Hawaii Institute of Geophysics, in asociation with the Testern State's Cooperative Direct Heat Geothermal Program, will help resolve these questions.

Table 1. Probable Prospect Locations

\begin{tabular}{|c|c|c|c|c|}
\hline ISLAND & $\begin{array}{l}\text { PROSPECT } \\
\text { LOCATION }\end{array}$ & $\begin{array}{l}\text { No. OF } \\
\text { WELLS }\end{array}$ & POINTS & $\begin{array}{c}\text { POINTS } \\
\text { PER } \\
\text { WELL }\end{array}$ \\
\hline \multirow[t]{5}{*}{ Hawaii } & Kawaibae & 8 & 25 & 3.12 \\
\hline & Rilo & 10 & 14 & 1.40 \\
\hline & Puna & 7 & 16 & 2.28 \\
\hline & Pabala & 7 & 7 & 1.0 \\
\hline & Kailua Kona & 4 & 5 & 1.25 \\
\hline \multirow[t]{3}{*}{ Maui } & Labaina & 3 & 7 & 233 \\
\hline & Mopua & 3 & 8 & 267 \\
\hline & Haiku & 3 & 4 & $\begin{array}{l}2.67 \\
1.33\end{array}$ \\
\hline \multirow[t]{6}{*}{ Oabu* } & Makaua & 6 & & \\
\hline & Lualualei & 4 & 20 & 3.33 \\
\hline & Haleiwa & 8 & 12 & 3.0 \\
\hline & Taimanalo & & 11 & 1.37 \\
\hline & Eonolulu & 2 & 6 & 3.0 \\
\hline & & 2 & 4 & 2.0 \\
\hline Kauai* & Libue & 4 & 9 & 2.25 \\
\hline
\end{tabular}



Table 2. Wells $>25^{\circ} \mathrm{C}$ and Depth Below Sea Level-
From HIG Progress Report

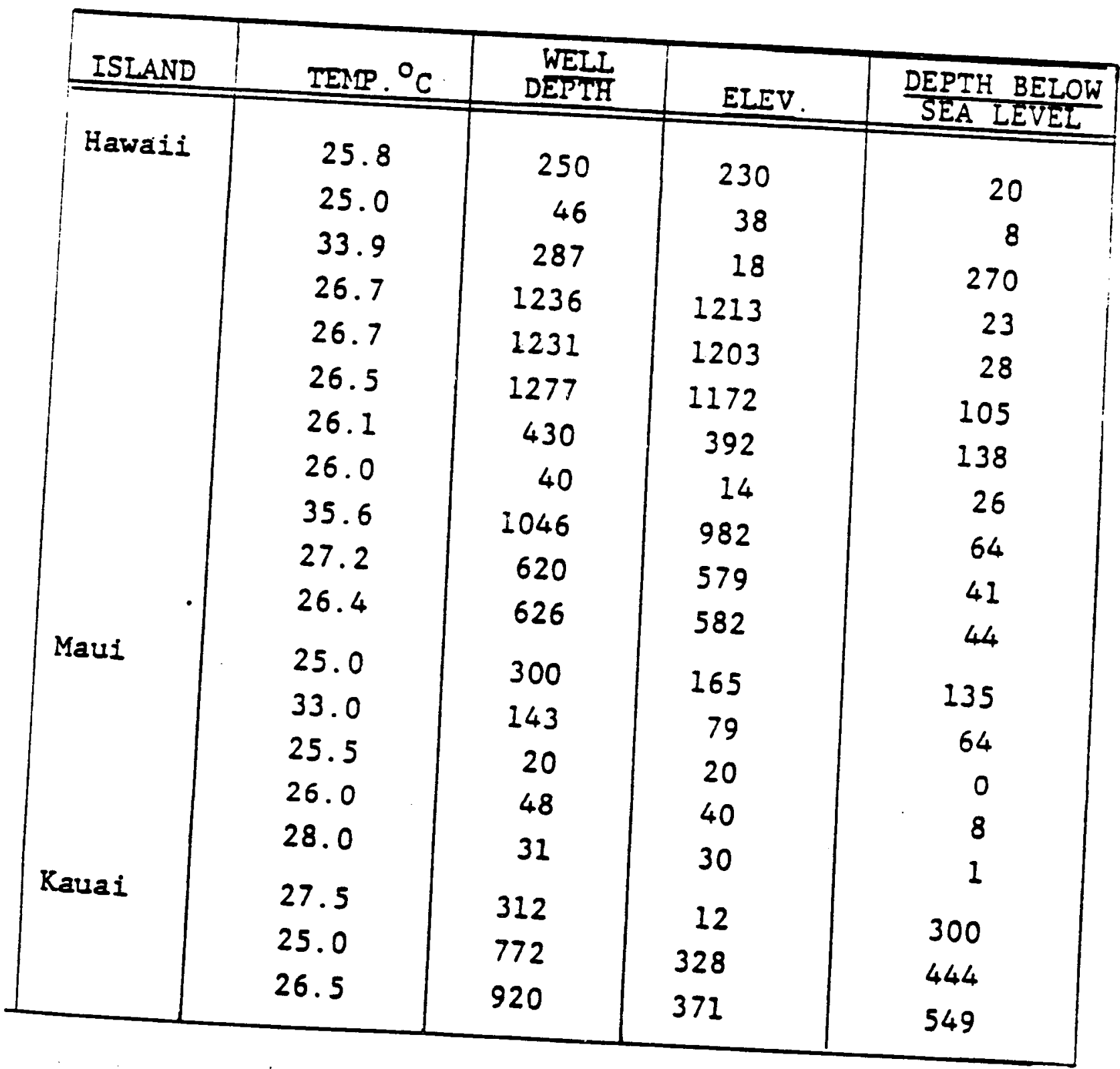




\subsection{POTENTIAL DIRECT USE APPLICATIONS IN HAWAII}

Two potential users of geothermal direct heat bave been identified which are not only large process heat users, but also industries unique to the state-cane sugar mills and aquaculture farms. A third possible user--the resort industry--bas also been considered. Based on the findings of the overview in terms of potential prospects and users, this section presents an analysis of the economic feasibility of utilizing geothermal energy directly in sugar mills, for replacing fossil fuels, and in aquaculture farms for raising fresb water and marine shrimp.

3.1 POTENTIAL USERS

Potential users of geothermal direct heat in Hawail, listed in Table 3 , have one noticeable difference from comparable users on the mainland--there is no space heating requirement due to the tropical climate. Other than this, the criteria used to develop the August 1978 Califoraia Direct Use Overview for the Department of Energy is useful for Hawaii. Site locations plotted on the Island Charts are presented at the end of this rection and Appeadix A.

An evaluation of potential users emphasizes the two Industries uniquely important to Hawail, which are also possibly the largest potential users of direct heat in the state. These two potential users are the sugar mills and aquaculture farms. hother possible important user is the large resort industry thlch is considered briefly. A listing is found in Table 4.

When evaluating other direct-beat users and hybrid lectric power production it should be recognized that lower mperatire resources can be used for pre-beating purposes lloolog the higher grade energy to top off the BTU requirements. is this way, high temperature uses can be augmented with lower 
temperature resources to provide increased applications of low and intermediate temperature geothermal resources.

Table 3. Hawaii's Potential Users of Direct Heat (Existing)

Agricultural Drying

Low Temperature

Fertilizer Mixing

Low Temperature

Aquacultural Farms

Low Temperatuse

Food Processing and

Canning

Medium Temperature

Hospital and Institu-

tions

Medium Temperature

Hotels and Condomiתivms

Mediun Iemperature

Sugar Mills

Lumber Mills

High Temperature

Electrical Generating Plants

High Temperature

High Temperature 
Table 4. Existing and Planned Hotels/Condominiums of More Than 100 Rooms (to 1980)

\begin{tabular}{|c|c|c|c|}
\hline ISLAND & EXISIING/BUILDING & UNIIS & $\begin{array}{l}\text { PLANNED MAJOR } \\
\text { DEVELOPMENT }\end{array}$ \\
\hline Hawaii & $\begin{array}{l}\text { Hilo } \\
\text { Waimea-Rohala } \\
\text { Kona }\end{array}$ & $\begin{array}{r}7 \text { each } \\
2 \text { each } \\
11 \text { each }\end{array}$ & $\begin{array}{l}1 \text { each } \\
3 \text { each } \\
\text { I each }\end{array}$ \\
\hline Maui & $\begin{array}{l}\text { Kahului } \\
\text { Lahaina-Napali } \\
\text { Kihei Waiela }\end{array}$ & $\begin{array}{r}2 \mathrm{each} \\
16 \mathrm{each} \\
8 \mathrm{each}\end{array}$ & 2 each \\
\hline Molokai & West & 1 each & \\
\hline Oahu & $\begin{array}{l}\text { Waikiki-Honolulu } \\
\text { Leeward } \\
\text { Windward }\end{array}$ & $\begin{array}{r}68 \text { each } \\
1 \text { each } \\
1 \text { each }\end{array}$ & 1 each \\
\hline Kauai & $\begin{array}{l}\text { Lihue } \\
\text { Wailua-Rapaa } \\
\text { Poipu-Rukuiula } \\
\text { Hanalei-Haena }\end{array}$ & $\begin{array}{l}1 \text { each } \\
9 \text { each } \\
3 \text { each } \\
1 \text { each }\end{array}$ & \\
\hline
\end{tabular}


In any steam plant, be it food processing, lumber, or electric power generation, economics of operation are dependent partialiy on the difference between the temperature of the steam entering the beat engine (turbine) and the temperature of the steam leaving the engine. This change in temperature is greatest wen the coldest possible condenser is used. The condensed water is pumped from the condenser to become feed water for the boiler in a closed cycle, and is characteristically close to the temperature of the condenser's cooling water.

In the larger and more efficient plants, the condensate/ feed water is pumped through several stages of heat exchangers, heated by bleed steam, to ralse its temperature as bigh as possible before intenters the boiler. Geothermal heat at any temperature may be used to displace the bleed steam which then can be allowed to expand completely throughout the turbine. The improvement in economy of existing plants may be limited by replacing bleed steam with geothermal heat because of the high capital costs associated with retrofitting to accommodate geothermal steam. The design of any new plant however, can be optimized for any temperature of geothermal (or otber) resource that may be available.

The ability to use such relatively low grade heat is characteristic of any condensing thermodynamic cycle where the resource temperature available is greater than the condensate temperature. The higher the temperature, the larger the potential economies for such use. Thus low, intermediate and high temperature geothermal resources can be used even in the conventional electrical generating steam plants, if the economies dictate such usage.

This concept of using geothermal heat in a hybrid system io augment standard fossil, waste or biomass-fired plants may be important if the ultimate resource assessment indicates relativeif shallow, low grade heat resources suggested by the numerous 
water wells above $250^{C}$ on most islands. If the use of low grade temperatures is considered in the initial plant design and the cost of obtaining the geothermal fluid is combined with that of a planned water well, for instance, the cost/benefit of the geothermal resource may be easily justified.

\subsection{SUGAR MILLS}

An engineering evaluation of using geothermal heat at the existing Puna Mill at Keaau is being undertaken by Amfac, Inc. The basis of the evaluation rests on the use of geothermal fluid to replace reduced pressure steam ( 15 PSI) for process heating. This would allow the use of existing high-temperature bagasse-fired steam to make additional electricity which is sold to the local utility company under contract. The Puna evaluation includes the following factors:

- A producing well(s) and necessary reinjection well(s) would be developed at a site not far from the existing geothermal well (HGP-A) in Puna on lands owned by Amfac, Inc.

- A binary system would beat fresh water and transfer it as high-pressure hot water through a pipeline along an existing right-of-way, from the known resource to the existing sugar mill at Keaau.

It is probable that because of the arailability and the associated difficulty of disposing of bagasse at all sugar mills, geothermal direct heat $\nabla 111$ be considered only by those milis that also produce electricity, especially when a contractual arrangement exists with the local utility company that can lead to burning oil when bagasse is not available. For these reasons, only the sugar mills that also generate electricity are considered as potential users and are plotted on the maps.

Sugar mills that sell electrical energy receive only a modest rate for this energy (in many cases equivalent only to the cost of the fuel oil saved by the utility company), therefore, a 
large economic incentive for them to produce electrical energy does not exist. Recent contracts for "firm" power, however, have considerably improved the rates being paid to the sugar mills for the electrical energy produced. This is the situation for Puna Sugar and is unquestionably a major driving factor in the cost/benefit analysis now being performed on the economic feasibility of using geothermal beat for process plant heat.

In addition, the sugar market has been depressed in recent years forcing several plantations and mills to close down and/or consolidate. This means that any large amount of capital investment funds will not be available unless other economic activities such as selling electricity from bagasse-fueled plants are considered feasible. The recently-announced new power plant at Libue, Kauai is a case in point. It will be a pilot project financed by Foster Theeler Corporation, a boiler manufacturer interested in testing the use of bagasse and other waste materials in its boiler.

\section{3}

\section{AQUACULTURE FARMS}

Over 600 acres of land in Hawaii are currently devoted to existing aquaculture farms; however, this amount is expected to increase rapidiy. One source unofficially predicted a doubling of acreage within the next two years. Fresh water shrimp, along with some shellfish (oysters) and fish (catfish, carp, and mullet) are the principal products of the industry. The growing market for prawns and shrimp indicates that there will be continued expansion of the farms.

The considerable quantity of fresh water required by aquaculture farms, especially those ralsing fresh water shrimp, is becoming an increasingly limiting factor in aquaculture development because of the growing competition for the available eresh water. A recent development in the breeding of salt water shrimp that promises a higher jield per acre, a higher market 
price and a larger market, is expected to have a beneficial impact on aquacultural farming in the near future.

One of the important factors in the profitability of aquacultural farming is the temperature at which the animal is grown, as this temperature influences growth rate. This varies with the species, but generally warmer temperatures, within an allowable temperature range, produce better growth rates. Table 5 lists the temperature ranges for several different aquacultural species. As can be seen from the table, the Hawaiian Islands' ambient temperature range of $20^{\circ}-26^{\circ} \mathrm{C}$ is at the lower end of the scale for the more temperate fresh water shrimp and is not adaquate for the marine shrimp.

Existing warm fresh water wells in Kapabo (Puna, Hawaii $33.9^{\circ} \mathrm{C}$ ), Kawaibae (Kohala, Hawait $35.6^{\circ} \mathrm{C}$ ) and Lahaina (Maui, $33^{\circ} \mathrm{C}$ ) are in a temperature range that could have significant impact on the local aquaculture efforts. Future planned acreage will possibly require drilling for water, and, given the possible additional benefit of higher temperature waters, such drilling can be planned to seek low grade geothermal waters for aquacultural usage.

Soon to be published is the state of Hawail's (DPED) aquaculture resource study which includes maps showing potential aquaculture lands in the state. The selection critieria includes the type of soil and slope of land for ponds. Table 6 presents a listing of the selected optimum potential geothermal prospect sites and a quantitative determination of adjacent lands for aquacultural use in terms of amount of land area listed as having good aquaculture potential.

The benefits of increased growth rates from higher (to optimum) temperatures of water for aquaculture are well known, in general, but the temperature ranges for specific types of organisms such as those which are now being farmed in Hawail are 
Table 5. Temperature Ranges of Several Different
Aquaculture Species

AQUACULTURE ORGANISM

Salt Water Shrimp (Tropical)

Fresh Water Shrimp (Temperate)

Mullet

Cateish

Oysters
IEMPERATURE RANGE

$25^{\circ} \mathrm{C}-32^{\circ} \mathrm{C}$

$22.2^{\circ} \mathrm{C}-31^{\circ} \mathrm{C}$

$3^{\circ} \mathrm{C}-35^{\circ} \mathrm{C}$

$25^{\circ} \mathrm{C}-33^{\circ} \mathrm{C}$

$10^{\circ} \mathrm{C}-32^{\circ} \mathrm{C}$ 
Table 6. Aquaculture Potential Adjacent to
Potential Geothermal Resource

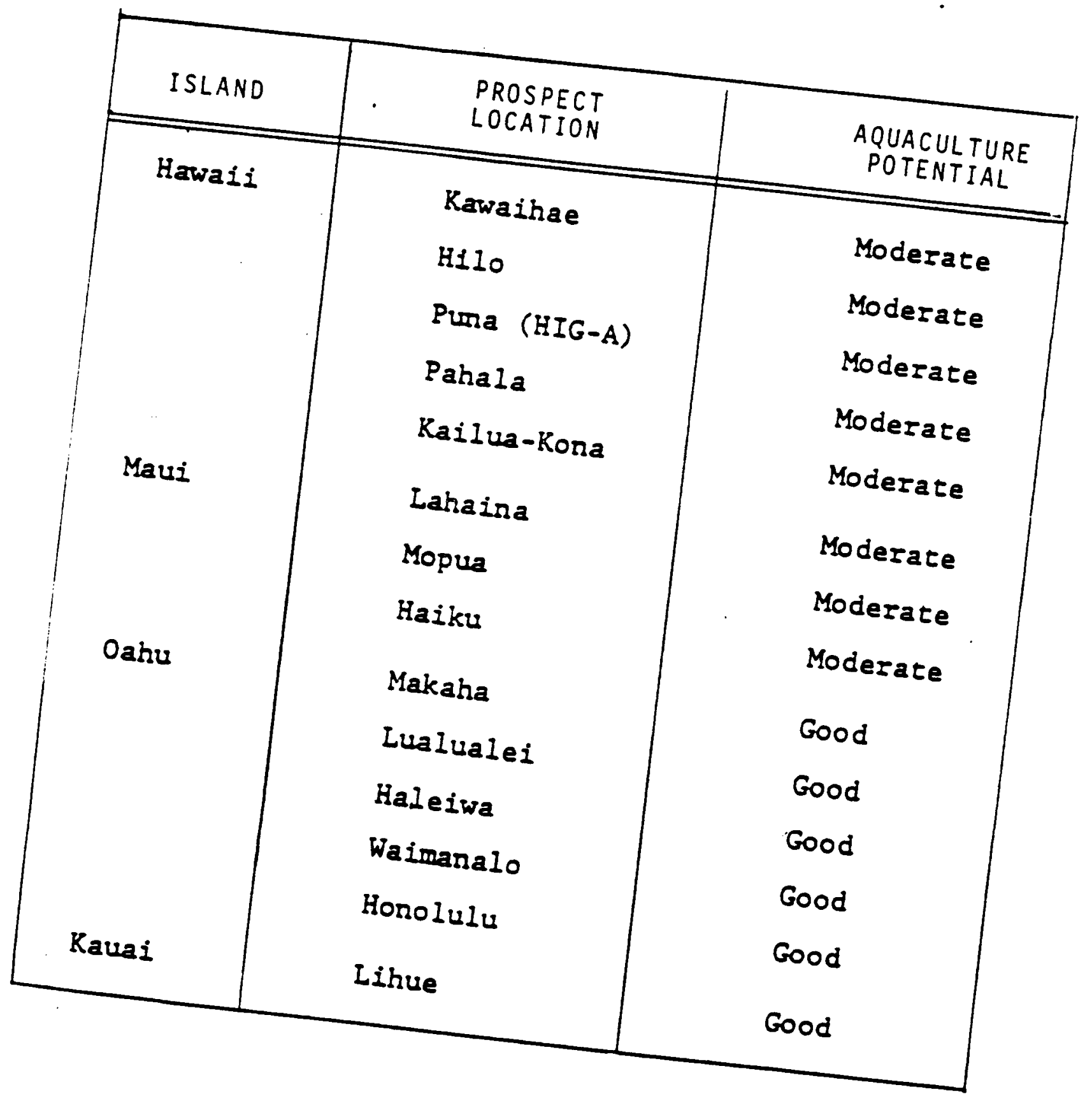


not so well known. The differences in yield will be the principal economic benefit of using $10 \mathrm{w}$ grade geothermal heat in aquaculture. Until such benefits are more definitely established for particular species and locations, it may not be possible to do an in-depth economic analysis.

The possibility of farming marine shrimp using a warm water resource is potentialiy very attractive because the inancial return for this type of shrimp is higher than for the existing fresh water variety.

3.4 ECONOMICS OF GEOTHERMAL DIRECT HEAT APPLICATION IN HAWA I I

The larger loeal corporations which control virtually all the potential sugar mili users, a good portion of the existing and potential aquaculture farms and a significant portion of the planned resort development represent the investors which geothermal heat will have to attract in Hawail. Typical selection criteria for new projects to be funded by corporate capital demands are currentiy a minimum of $25 \%$ return on investment after one to two jears from the start of the project and 30\%-35\% minimum to be considered for further evaluation beyond an initial screening. These relatively high rates of return on investment in Hawaii comprise the existing market for capital funds, and any geothermal energy project will have to compete in this market. The study, currently under preparation, on the utilization of geothermal direct heat at the Amfac, Inc. Puna Sugar Mill is a case in point. When the cost/benefit analysis is completed, the rate of return will be evaluated and compared with other candidate corporate projects in order to determine which projects will receive the arailable capital funds.

However, there is another important segment of users-the small users. One example is the privately funded effort of the Puu Waa Waa Ranch where a well is being drilled above KailuaBona on the island of Hawail at 3,000 foot elevation. Originally 
intended as a water well for use in this dry area, apparent indications of an existing geothermal resource were sufficiently strong that an application for a geothermal test well will be filed with the State of Hawail by the Puu Waatra Ranch.

In order to demonstrate the economic viability of geothermal energy in Hawali, a preliminary economic analysis was prepared for the concept of a direct use industrial park at Keaau which is near the Puna site in Hawail. The concept for the Keaau site is to use the waste heat from a well head generator located at Puna to heat fresh water and pipe it 18 miles to the industrial use. The following parameters were estimated for the Keaau application.

Table 7.

Economic Parameters For

Hypothetical Keaau Direct Heat Application

$\begin{array}{ll}\text { Cost of Mell } & \$ 1,500,000 \\ \begin{array}{l}\text { Cost of Pipes, Distribution } \\ \text { System, Heat Exchangers (18 } \\ \text { Miles of Pipes) }\end{array} & \$ 3,000,000 \\ \begin{array}{l}\text { Yearly Operating and } \\ \text { Maintenance }\end{array} & \$ 400,000 \\ \text { BTU's Delivered } & 4.1 \times 10 " \text { per year } \\ \text { Return on Investment } & 12 \% \\ \text { Financing } & 75 \% \text { debt } 9 \% \text { interest } \\ & 100 \% \text { equity financing }\end{array}$

Using the GEYSER model, it was determined that the cost of process heat would range between $\$ 2.03$ and $\$ 3.14$ per million BTo's. The recent tax incentives granted in the National Energy Act can have the impact of lowering this cost to between $\$ 1.30$ and $\$ 2.18$ per million BTr's, which is highly competitive with the price of oil, which is presently in the range of $\$ 2.50$ per dlion BTU. This analysis did not include the right-of-ray 
costs for the 18 mile pipeline, which could possibly be a large cost. It may be more cost effective to risk drilling a well at Keaau or elsewhere nearby in order to eliminate the piping costs and acquisition and implementation problems, should geophysical prospecting results be positive.

3.5

FINDINGS AND RECOMMENDATIONS

It is recommended that further efforts applied to geothermal direct heat applications in Hawali be directed toward three areas:

- Use of low temperature beat from existing or potential fresh and brackish water wells for optimizing gield (growth) rates of commercial aquaculture farms. (Applicability is statewide).

- Evaluation of using all ranges of temperatures of geothermal heat in existing and planned steam cycle plants of all types, including the beating in electrical generating plants and sugar mills. (Applicability is statewide).

- Use of medium grade temperature resources by large resort developments for space conditioning, water heating, health spas, swimming pool heating, etc., as appropriate. Such a resource can possibly be part of a fresh water well system for such a facility. Application is especially noted for the dry areas marked for resort development such as Makaha, Oahu, Kawaibae-Kona, Hawail and LahalnaNapal1, Mau1.

Resort development is a continuing activity in Hawaii, mpecially in relatively remote and secluded areas. These sites :!ted do not have existing utilities such as fresh water, so the seloper is usually required to drill for water.

At the locations of sersial currently-planned developmis, if the developer was encouraged to drill deeper in an liempt to locate geothermal low temperature water, he could use Darw or hot waters for several direct use applications in 4 development including pool heating, spa heating and water 
heating. If the change in temperature of the extended fresh water well was rapid en ugh to indicate a nearby intermediate temperature geothermal resource, the developer could use such heat for space cooling as well.

Sugar mills will continue to evaluate where potential direct heat use may apply in existing and planned sugar mills and where it can replace other primary fuel that would normally be used for generating electricity that is sold. Because of its close proximity to a proven high temperature resource, the current puna sugar Mill study should identify the potential economic advantages of using geothermal direct heat for the most favorable terms. Any implementation of direct energy use by this plant 111 undoubtedly result in rear optimum plant configuration, a fact all such sugar milis should consider.

Knowledge of existing warm water wells should be disseminated as widely as possible to the aquaculture industry. The plots of the potential geothermal prospect areas as listed in this report may have utility to potential users in search of warm waters which can result from extended depth drilling for fresh water at any location near a potential geothermal resource.

Studies and analysis of existing information concerning the effect of temperature on growth rates of different mariculture organisms need to be undertaken and subsequentiy distributed to potential users.

Figures 2 through 5 are charts of potential users and resource locations. Figures 1 through 5 are based upon more detailed maps which are presented in Appendix A. 
beating. If the change in temperature of the extended fresh water well was rapid enough to indicate a nearby intermediate temperature geothermal resource, the developer could use such heat for space cooling as well.

Sugar mills will continue to evaluate where potential direct heat use may apply in existing and planned sugar mills and where it can replace other primary fuel that would normaliy be used for generating electricity that is sold. Because of its close proximity to a proven high temperature resource, the current puna sugar Mill study should identify the potential economic advantages of using geothermal direct heat for the most favorable terms. Any implementation of direct energy use by this plant will undoubtediy result in a near optimum plant configuration, a fact all such sugar mills should consider.

Bnowledge of existing warm water wells should be disseminated as widely as possible to the aquaculture industry. The plots of the potential geothermal prospect areas as listed in his report may have utility to potential users in search of warm nters which can result from extended depth drilling for fresb ater at ang location near a potential geothermal resource.

Studies and analysis of extsting information concerning :he effect of temperature on growth rates of different marialture organisms need to be undertaken and subsequentiy $\because$ stributed to potential users.

Figures 2 through 5 are charts of potential users and isource locations. Figures 1 through 5 are based upon more inlled maps which are presented in Appendix A. 



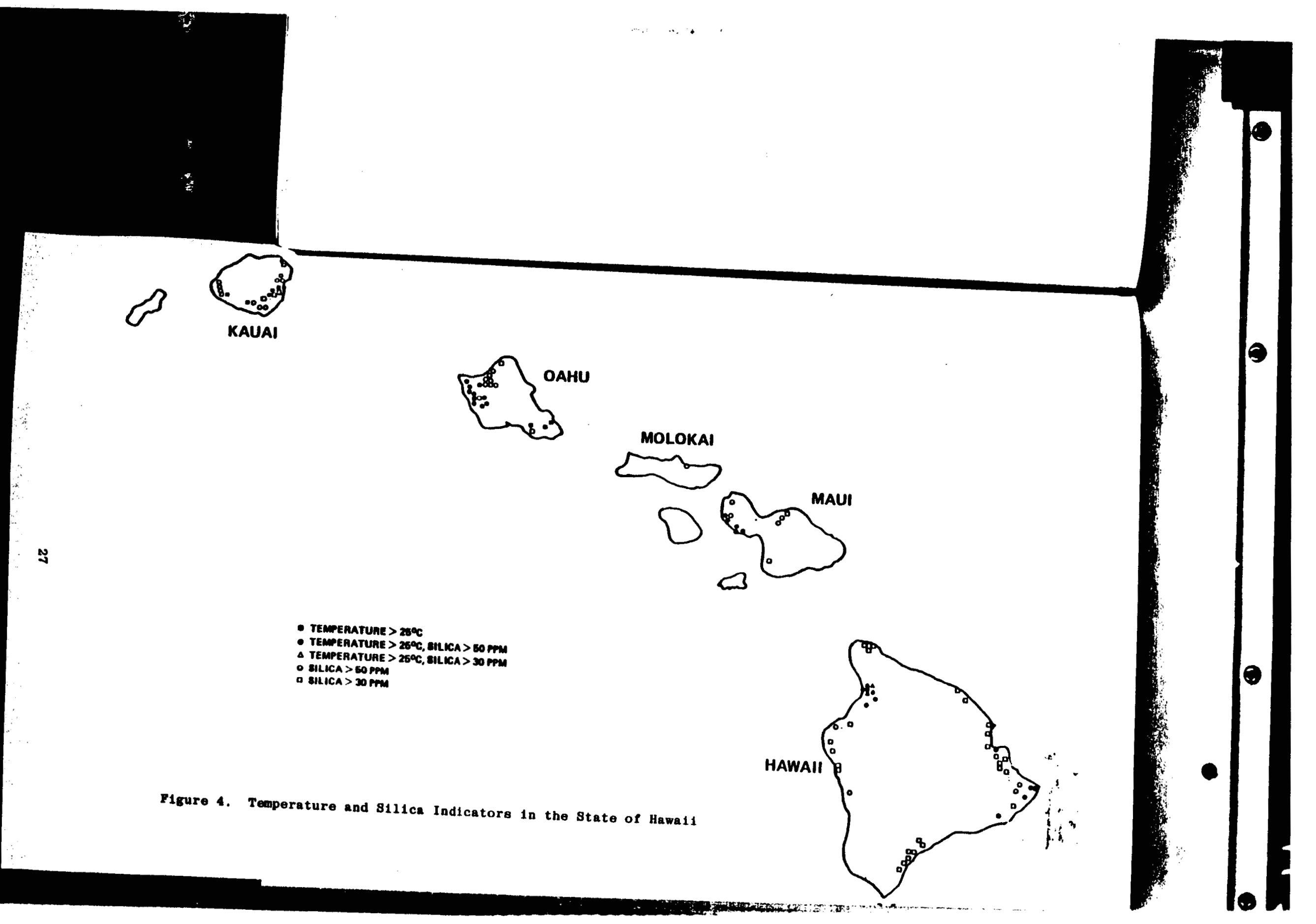


The first three ecctions of this report consist of an overview of direct use applications of geothermal energy in the State of Hawaii; in this section, a projection of geothermal resource development is presented for the Puna prospect, on the Eig Island of Havail. Puna is the site of the HGPA well, possibly the hottest geothermal well in the world, with temperatures of approximately $676^{\circ} \mathrm{F}$ at 6,450 feet. The purpose of the scenario is to identify program needs and to provide a basis for monitoring progress.

\subsection{PUNA NEAR-TERM COMMERCIALIZATICN AND LONG TERM DEVELOPMENT}

Extensive development of geothermal resources in the Puna district must be considered quite speculative at this time. Available estimates of the potential are based on data from one borehole, the presence of recent volcanic activity, and reasonably extensive geophysical investigation. Estimates of the potential are as high as $5,000 \mathrm{MH}$ electric for 100 years, assuming that the whole area of the Kilauea rift zone is as hot as the existing borehole, and at similar depth. Further exploration is needed to establish the potential magnitude witb confidence.

If one assumes that a moderate fraction of this potential is developable, the local demand or market is not enticing without a large addition of industrial demand for electrical power. Even the addition of much expanded thermal demand (direct uses of heat) can be seen as having only gapfllifig or smootbire effects ou the development of significant electrical power uses. 
Of the industries strongly considered as appropriat this area, only manganese nodule and aluminum reduction fa ties require the magnitude of power production envisione potentially avallable. Each of these is subject to limita in economics and timing.

Two immediate activities seem to bear most imminentl the longer future of geothermal development in the puna distr: These are the Puna Sugar Company direct use study, and possible further exploration in the vicinity of the exist borehole at Puna.

The Puna Sugar Company study is at the stage of dete mining the feasibility and cost of constructing a pipeline carry steam from near the Puna site to the sugar mill at Reaa More definite data from geophysical analysis of the area by $t$ University of Hawail Institute of Geophysics (Professor Helsle: is needed before tbe potential alternative of drilling additiona wells at Keaau is considered. The manager of the Puna Sugar Mil would only comment that any definite predictions seem premature.

Exploration driling extended from the existing successful borebole is required to confirm the reservoir, that is, to provide data necessary to estimate the extent of the reservoir. Timing of this drililing is becoming critical. It appears that the small demand or market available in the near future and the concerns produced by perceived administrative and legal uncertainties have limited the number of potential developers for the near-term.

There is near-term interest in the Puna site by at least tro entities, the Tokyu Land Development Co., which orns land in prosimity to the existing geothermal well, and GEDCO, which has a special use permit and would like to drill in the area. Financlog is currently the major issue wich is retarding developwent. both companies are considering the development of a 20 un power 
plant in the Puna District. Tokgu is presently attempting to put together a consortium of interests to develop the site, and GEDCO has been generating some interest by investor parties. One method of financing such an endeavcr would be to use a geothermal loan guaranty. Elther one of these companies or both together might apply for a loan guaranty. Because this is a possibility, an optimistic scenario for a $20 \mathrm{~m}$ power plant is included in the Puna integrated scenario. The scenario indicates that power could be on-line by 1983; however, this is unlikely because the demand for power by the local utility will not be sufficient unt 111985 or 1986. The scenarlo for development in this case is limited by near-term demand.

The scenario may also be limited by immediate business constraints and opportunities. It appears that if GEDCO cannot arrange to be drilling in Puna by July of 1979, it will abandon plans for further work in Puna district. (See Figure 1 for detailed schedule.) This urgency is predicated upon a variety of controlling factors unique to this operator (related to risk capital availability).

Running strongly through Puna and, for that matter, the wole State of Hawail geothermal development scheme is the fact that the potential demand for geothermal energy is limited to a relatively small-scale utility demand, unless major transformations in fuel pricing or legislation favoring geothermal energs occurs.

It is difficult to make a definitive prediction about the future of manganese nodule or aluminum reduction plants in the area within the next ten years, without knowing at least tbe agoltude of potential geothermal resources and costs of energy delivered. The consensus seems to be that only the drilling of exploratory boles 111 provide the inputs necessary.

Thile major corporate developers bave adopted a iteptical view of achieving an acceptable short-term return in har because of the present imited demand, the GEDCO operation 18 geared to be satisfied by a relatively small potential, in the 
near-term. However, even they find that their economic position becomes untenable if they are unable to move directly from their present drilling site in Kona to a site in Puna or elsewhere. Their permit to drill in Puna, which expires in July 1979, was extended to that time by Hawail County and the Land Use Commission, as a one-time proposition.

The drilling equipment this operator has been keeping in Hawaii is the only equipment which is located in the state and capable of drilling to the required depths. This type of equipment is in short supply elsewhere and would bring a favorable price on the market, thereby, producing additional pressure for a decision early in 1979. The lack of such equipnent and the resulting virtual end of the interest on the part of GECCO would constitute anotber economic barrier to early exploratory driling in the puna area.

ARCO and others have apparently lost enthusiasm for the area, and concern for volcanic events expressed by the electric utility act as definite dampers on what previously was an optimistic expectation for geothermal comercialization in the Puna area.

The need for industrial consumers of large amounts of energy affects the potential for comercialization by discouruing financing. Traditionally, wildcatters and drillers are not qualified for or very interested in developing a market for energy they find, prove, and develop. Traditionally, that market the been assumed.

Nonetheless, opportunities for development exist. Three development scenarios are presented in Figure 6. First, the vllbead generator project which is in progress. Second is the rosible direct" heat application for the Puna sugar company. Mird is a possible 20 ume power plant. The PERT-type diagram :llustrates the time-sequence and precedence relationships of 


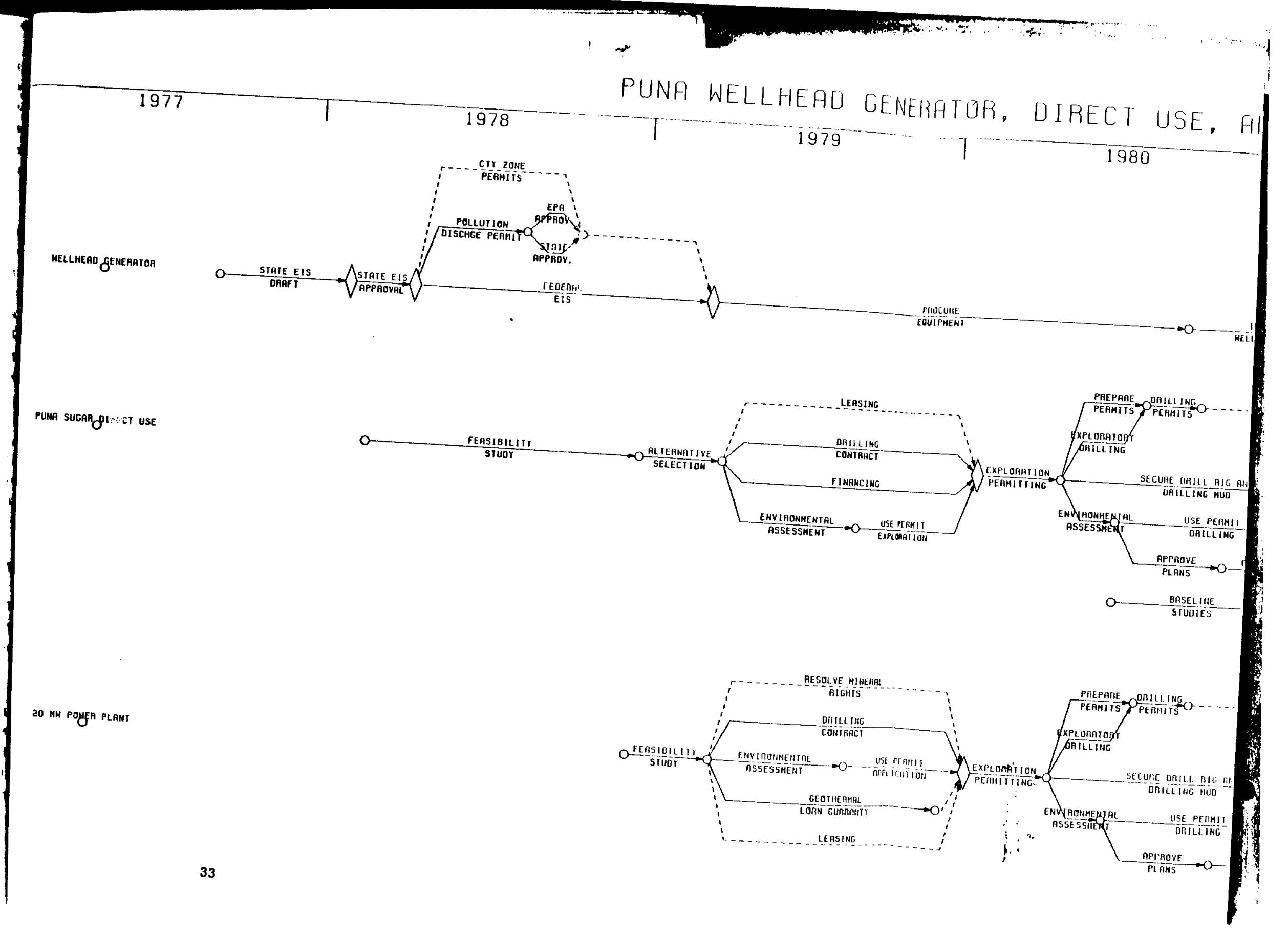


activities which must take place leading to power on-line. T scenario indicates that the wellbead generator could be on-li. in early 1981, the direct heat application by early 1983, and $t$; 20 uTe plant by the end of 1983.

The scenario for the 20 MWe plant assumes that th process will start from early 1979 at point zero. This is th stage that the Tokyu Land Development Co. is at now if GEDCO $i$ not a part of the consortium. The scenario is optimistic an allows for a 3 month feasibility study before application for: geothermal loan guaranty, special use permit, and leasing o: additional lands. The loan guaranty mould presumably be grantec on the grounds of the existing well, HGP-A. GEDCO already bas : special use permit at Opibahkao in the Puna District, so the scenario could be moved forward 6 months to a year. GEDCO may get financing to drill a well in the area, and, if successful, might then apply for a geothermal loan guaranty. The optimistic scenario indicates what could happen given sufficient impetus, but unless there is a drastic push on the part of the utilities to displace oil fired plants, the demand for energy would not be adequate to absorb the incremental 20 MWe until 1985-86. Some of the issues such as the resolution of mineral rights may take longer than postulated in the scenario because the decisionmakers perceive a long interval before the power is needed.

The timing uncertainties caused by administrative requirements (including permitting), resource ownership problems and the lack of a clear market for the energy discovered, has dampened the enthusiasm of the flnancial/development community. Some members of that commuity believe that proof of this reservoir in the near-term ( 1 gear) will probably require a aumber of matters to be resolved with unusual speed, $1 . e .$, by very early in 1979. This will call for land position, financing, permitting, and equipment combitments to be resolved (at the 
minimum) in this time frame: If not, the prospect of commercia zation in Puna may be limited to uses of the existing borehole Kapoho for many years. 
Any hope of substantial (25 MW or more) demand for pow from geothermal resources in Puna for the next 10 years or long is dependent upon location nearby of relatively large industric demand centers in the area. Domestic and direct use demands ar expected to grow, but they are relatively small and subject $t$ satisfaction from other indigenous sources, such as solar an sugar mill waste products, with OTEC and wind energy a: additional factors under consideration.

The potential for development of manganese nodule or aluminum reduction plants interacts not only with the locally available geothermal power, but with comparison of its price on a farorable economic scale. The continued availability of cheap power, such as hydroelectric or cheaper geothermal power in other areas of the world (and more or less favorably located), the willingness of local government and the federal departments to assist in creating a favorable investment climate, and acceptance by the local citizenry are only some of the major elements affecting decisions to be made. Changes in worldwide monetary conditions, the competitive value of the final product, and other competitive considerations not exclusively affected by local or national policy are also part of the equation.

The demand-potential prediction is bardly affected by plans of the local utility company. There is real doubt whether the needs of the local utility system would justify, on a purely economic basis, even the two or three additional exploratory holes thought to be a minimum requirement to prove the resource. Given the prospect of additional power avaliable from sugar mills near Hilo, it is likely that even the near-term demand increases on the windward side of the island might be met without encouragement to geothermal development. The cost of needed new transmission facilities tends to encourage the development of 
geothermal energy in Kona in favor of the Puna prospect from utility's point of view.

The potential for development of Puna geothermal $f$ electric purposes is seen to be primarily tied to industri. development. From a local planning standpoint, this is present: recelving positive impetus from the Hawail County planin Department through tentative plans to create industrial park designations in the general plan, in the area from Keaau to Hilo

\section{3 \\ IMPEDIMENTS TO COMMERCIALIZATION}

The usual mainland impediments are present in Hawail, along with unlque local inpediments. The latter are briefly described bere.

\subsubsection{Resource Ownership}

Ownership of the resource in Hawail is unclear. Historically, land grants in Hawail go back to the nineteenth century effort of the Hamaiian King Kamehameha to distribute land by grant (The Great Mabele) with reservation of mineral rights to the monarchy. A variety of questions arise, in attempting to determine the legal owner of title to the resource estate when tracing ownership through successive governmental forms from kingdoms through a republic, a territory, to the present statehood form. This is particularly true when the subject of ownership is ambiguous due to the state of Hawail claim of minerals reservation and the surface owner who claims the fee simple estate. Apparently, this uncertainty adds a serious dimension of risk in the minds of prospective developers of geothermal resources. 


\subsubsection{Hawailan Native Claims}

Bawailan native claims extend from a spiritual conce: for the development of the resource as a violation of the goddes Pele to a claim of legal right to the ownership of the resourc and to the control of its development. The people holding thes positions are not formaliy well organized, at least as viewed b state and county officials, and are therefore difficult to dea. with in any formal way. The assertions by their representatives, then, all seem to take the form of disruption and, as presented, are hard to view as constructive. It is clear from talking to the proponents of Hawailan native claims that they do wish to be constructive. They simply find that they do not have the time or financial resources to prepare formal presentations of their positions or to organize their constituency to present a united and influential posture in formal proceedings.

\subsubsection{Regulatory Requirements}

State Administrative Regulations and State Land Use Laws are not in harmony. A case in point: the previously-reported policy decision by the Land Board to permit "temperature holes" to be drilled with the same informality as that required for water wells has since been clarified to mean only "temperature holes" 500 leet deep or 1ess. Therefore, it is necessary to acquire a drilifing permit for an exploratory driling project deeper than 500 feet. This is deemed to be a declaration of geotherwal operation by the County of Hawail, thus activating a requirement for a Special Use Permit for projects on land with a land use classification of "Agriculture." This is the situation vith the GEDCO project in the Kona District of Hawail County, and it is reportedig now in the process of resolution. The drilling bad progressed to a depth below 500 feet before it was known to be in conflict (based on the intent of the project operator to produce water and to explore for heat). If heat was found, the operator intended to then apply for a special Use Permit. 
According to the most recent rulings, he will be required to cease and desist drilling, even thougb he has a state drilling permit, while waiting the three to six months required to acquire the Special Use Permit -- an economic disaster.

\subsubsection{Limited Demand for Energy in Puna}

The relatively smali existing demand for energy in Hawaii County and the difficulty involved in serving demands elsewhere, labibits immediate strong interest in comercialization on the part of large entrepreneurs. The problem of security from nearby lmminent volcanic eruption also tends to dampen enthusiasm in the puna area. Therefore, speculative risk capital for early exploration phases is not as arailable in Hawail as it is typicaliy in a mainland setting.

\subsubsection{Ongoing Research and Development}

Even the wellhead generator project can, in some sense, be vieved as an impediment to more immediate development, at least to the extent that it justifies a "wait and see" attitude, supports the "experimental laboratory" categorization, and tends to satisfy a small portion of the demand for power. Of course, it is viewed as a positive influence on commercialization plans for the longer future, in terms of a discovery and demonstration project.

\subsubsection{Compet1tive Energy Sources}

The development of additional power for sale by sugar processing mills on the island could alleviate the immediate need for additional power for the utility grid, and more firmly establish the thesis that any large-scale commercialization of geotherma?. resources in Puna will require an equally large-scale contract ith an energy-intensive industrial user. 
The Puna district of the island of Hawaii is south of Hilo, the county seat. The HGPA geothermal borehole, in the center of the district, is the first major event giving impetus to further development of geothermal resources. It is also the site of the wellhead generator project. Figure 7 displays the Puna integrated scenario to the year 2020.

Previous scenarios for the area have focused on the wellhead generator and potential direct uses of geothermal resources in the period through 1982. The purpose of the present scenario is to cast the potential commercialization of geothermal resources in Puna district in a more protracted time setting $(1980-2020)$. It is predicated upon the assumption that an optimistic outlook and an early encouragement of exploration extended from the original successful borehole at Kapoho can justify some very exciting expectations for geothermal commercialization.

Some basic assumptions have been made for the scenario development; many of these assumptions are interrelated and interdependent. The large and quantifiable aspects of the scenario are based on a large increment of industrial development by energy-intensive industrial operations such as manganese nodule and aluminum reduction facilities. The basic assumptions are:

1. A large reservoir of heat is in the kilauea rift zone running through Puna (as yet not proven).

2. This reservoir can be produced to be competitively priced (at least at a stable price) and in quantity that will compete for use by energy-intensive industry.

3. The residente in the Big Island of Hawaii will approve the geothermal power commercialization and industrial development. 


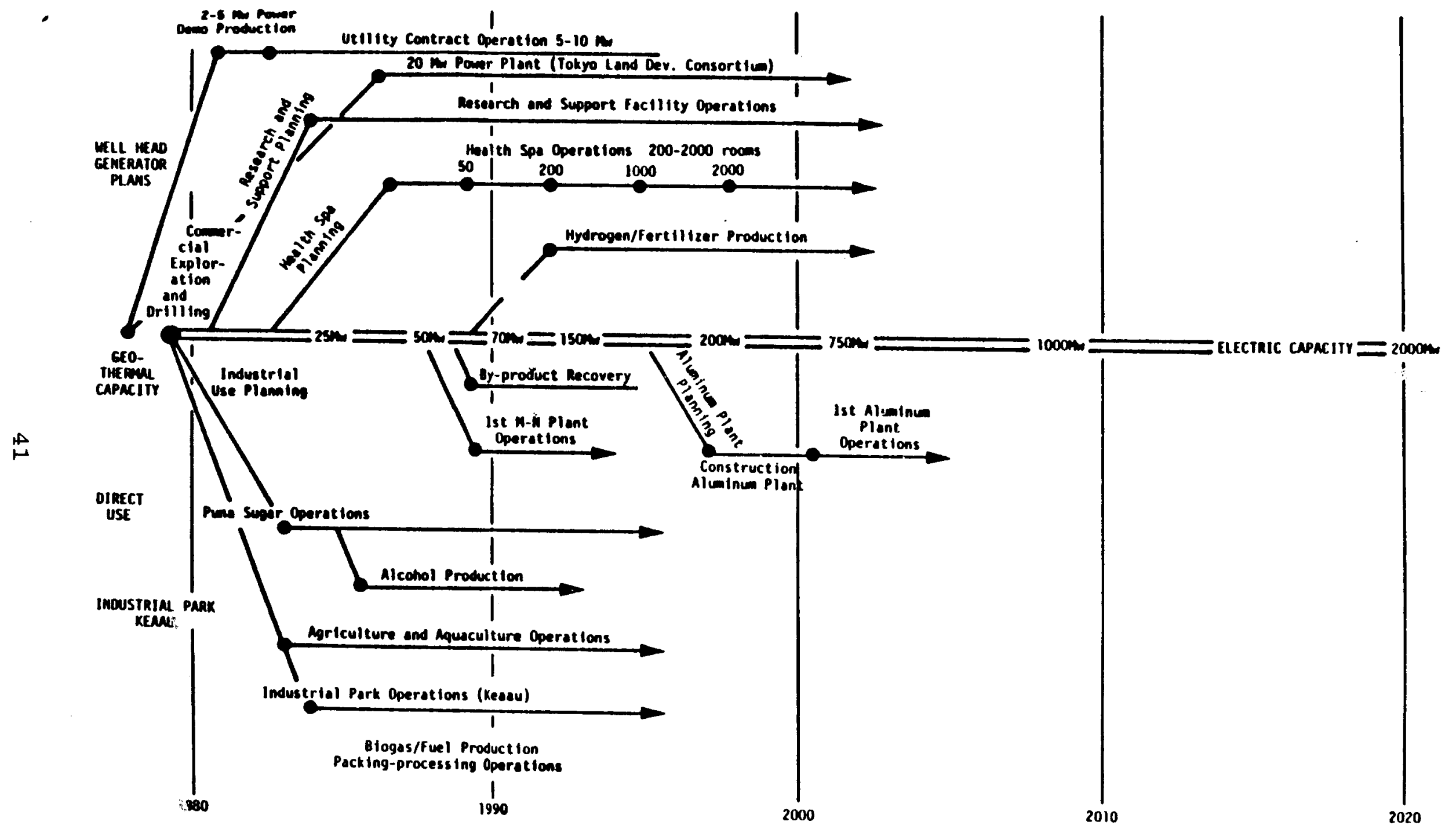

Figure 7. Overview - Puna Integrated Scenario - Geothermal Energy Commercialization 
4. Location of generating plants and steam gathering Iine systems will become better understood in order to overcome security objections.

5. The exploratory proof of the resource will not take place so late as to diminish the potential competitive position of the area.

6. Inexpensive energy will become unavailable to energy-intensive industries in existing locations, and energy price stability will increase in importance vis-a-vis location or relocation of these industries.

7. Political stability of a U.S. location having geothermal resources will favor Hawaii over locations in developing nations similarly endowed (such as those in Central America or in Indonesia).

Predictions of the reservoir potential in Puna range as high as $5,000 \mathrm{MW}$ for 100 years. This kind of prediction presupposes that the Kilauea rift is extensively underlain with heat of extractable values similar to that found at the Kapoho site. Only a sufficiently large exploratory and development program can prove this thesis to a degree beyond educated speculation.

If these predictions are true even to a degree much less than half that magnitude, it appears that by the year 2020 the infrastructure requirements and those of planning and construction would become the limiting constraints. Rational development of the geothermal resources also requires that all necessary factors take place in appropriate sequence. The experience at The Geysers in California is helpful in this regard. It is doubtful that the more insular and isolated Hawaiian setting yould be capable of a more rapid resource development.

Given that the major geothermal developments would keyed to serving the major industrial demand, the rate at Which these demand centers could be constructed and placed jo-line also constitutes a critical limitation. Considerations 
of eonomic appropriateness could be delaying factors of ultimale significance in this regard. However, if the decisions to locate these industries in the puna district are made by about 1985 1995, then the scenario will be reasonably accurate. These decisions will not be seriously considered in this time frame in absence of early and successful exploration and reservoir analysis of the resource base.

While the scenario postulates nearly an order of magnitude increase in electric power production in the 1990 and 2000 time frame, it does not seem possible to sustain that rate beyond the year 2000 because of infrastructive limitations in the local area. Also, it is felt that a faster rate of growth would meet with the opposition of local citizens.

Environmental considerations will affect the development by influencing costs of construction and operation. These environmental values are heavily supported by local citizens who in many cases have little to gain by industrial development. Careful planning and public awareness educational programs will be vital in this regard. Public review boards should include members of special interest groups in order that the latter perceive thermselves as part of the planning process rather than victims of it.

In adition to relatively large energy intensive industrial developments, there are many prospective peripheral and supportive service industries that will be a concomitant result. Possibilities of shared uses, direct heat uses, and interruptible uses of the power developed primarily for the major industries, play an important part in the scenario. Alcohol, Dethane, hydrogen and other chemical production facilities fall into this category, along with direct uses of relatively low temperature fluids il food processing industries. Agricultural and aquacultural operations are also capable of being enhanced by use of discharge heat values from electical generating 
facilities. Excess electrical capacity could be used for pumping energy and other appropriate purposes such as pulping and production of building materials and in preparation for composting and biogas production from waste products.

As mentioned above a specific study to assist in determining the commercial feasibility of using geothermal heat values directly in the sugarcane processing cycle at the puna Sugar Mill is currently in process. It has been determined to date that the intermediate process heat requirement ( 160 psi at $245^{\circ} \mathrm{F}$ ) theoretically could be transmitted to Keaau from the Puna well with a net loss in transmission lines of about 10 percent. The price of such a pipeline is tentatively calculated to be about $\$ 12$ milion. A number of problems associated with rights of way, not yet solved, can constitute major barriers. It may be that a 1983 date for start-up at this site is optimistic. As yet, no firm decision has been taken to go further than a study and analysis contract.

If the decision to go forward with direct use at Puna Sugar Mill is positive, it would tend to encourage greater reliance on sugar mill power and discourage reliance on geothermal power in the utility grid, thus reinforcing the need for contract, or energy intensive industrial uses, as the major push supporting extensive commercialization of geothermal resources in Puna.

Other potential direct uses of geothermal resources vould initially take the form of lower intensity uses for temperature control in growing and processing operations which can benefit from use of waste or excess heat from sugar mill operations and generating plants. In time, these uses can grow io provide a considerable push toward commercialization, but only When considered in combination wita and as adding to other lemands. Drilling depths, and therefore costs, in Hawaii, tend : require a heavier demand per drilled hole and also place 
low-density, smaller projects in a Jeripheral or supplemental demand status.

4.5

RECOMMENDATIONS

The following recommendations evolved from the analysis of factors encompassed in the Puna integrated scenario.

- Federal, State, and County governments, in concert 7 or separately, should provide the financial incentives required to encourage the exploratory drilling necessary to prove the Puna geothermal reservoir in the next few months. In order to complete exploration drilling in 1979, it appears necessary that the Federal, County, and/or state provide a major share of the required funding.

- An economic and marketing analysis of the potential for use of this resource should be performed with an emphasis on energy-intensive industrial processes. The emphasis should be on determining what factors are most important in the decision-making process for a potential company to select the Puna area.

- Tax and other location and relocation incentives should be devised based upon the findings in the economic and marketing analysis. An integrated program should then be enacted to encourage energy intensive industries to locate in the Puna district. A promotional/marketing program should also be conceived based upon these findings. This program should then be instituted by the state and County to encourage location of desired industries in the Puna district.

- State and County administrative laws and regulations should be altered to remove conflicts and therefore impediments to exploration to discover and prove geothermal resources, while coincidentally preserving environmental and safety values as locally determined.

- The matter of apparent conflict between State and private ownership of the resource should be clarified and settled by appropriate legislation, policy decisions and agreements in the near future. A procedure including some form of escrow arrangement should be developed to allow development to proceed while certain unresolved points and decisions are being considered or litigation is underway. 
- The native claims issues should be clarified tbrough a formal decision or litigation in order to determine not only the rights to ownership of the resource, but also to clarify the proper position of native Hawailan people in the planning process and the decision-making forum, on an ongoing and formal basis. 
1. Atlas of Hawaii, University Press of Hawaii, 1972.

2. "An Inventory and Analysis of the Electric Energy Industry in the State of Hawai," Pacific Analysis Corporation, Contract DACW84-77-C-0012, March 29, 1977.

3. "Kawail Geothermal Resource Assessment Program: Progress Reports \#2 and \#3," University of Hawaii, Hawaii Institute of Geophysics, Contract EW-78-S-07-1713.

4. "Hawaii State Aquaculture Study," Department of Planning and Economic Development, November 1978 .

5. "Hawai Visitor Plant Inventory," Hawaii Visitors Bureau Research Department, June 1978.

6. Physical Resources, State Tourism Study: Volume 1, Department of Planning and Economic Develoment, 1978.

7. "Regional Operations Research for Development in Hawaii, Report on Tasks 2,3 and 6," Pacific Analysis Corporation, Contract ET-78-C-03-1529, April 1978.

8. "An Overview of Prospects and Potential for Development of Geothermal Energy for Direct Use in California," Science Applications, Inc., August 1978 .

9. "Opdate and Extension of Puna Integrated Scenario," Action Resources, Inc., December 1978 .

10. "Report on an Overview of Direct Use of Geothermal Energy for the State of Hawaii," Pacific Analysis Corporation, November 1978 . 


\title{
APPENDIX A
}

\section{Geological Structure Maps and Resource Indicators for The Hawaiian Islands}

\author{
Legend for the Island structure Maps \\ Figure A Hawaii structure \\ Figure B Maui Structure \\ Figure C Molokai Structure
}

Figure D Oahu Structure

Figure E Kauai structure 


\section{LEGEND FOR THE ISLAND STRUCTURE MAPS}

(Figures A through E)

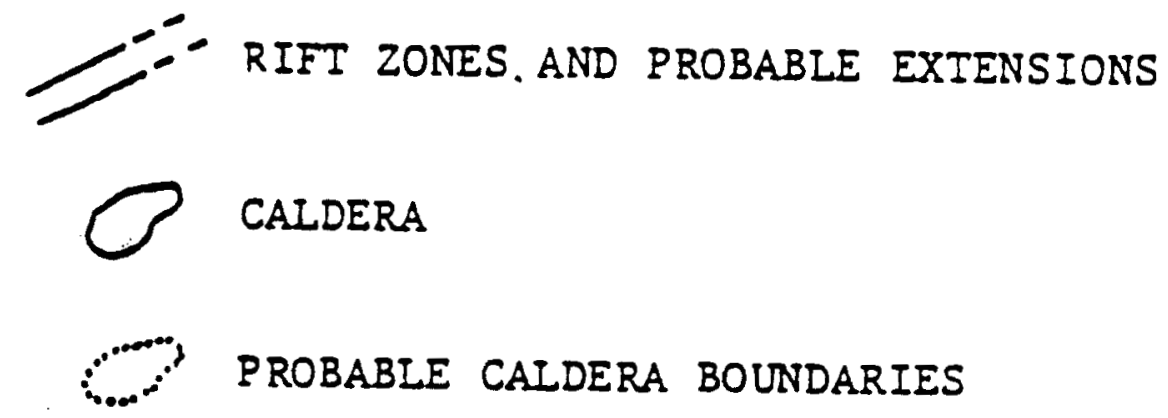

ONE MILE QUARANGLES; ONE OR MORE WELLS PRESENT WITH:

- temperature $\geq 25^{\circ} \mathrm{C}$

$O$ SIIICA $\geq 50 \mathrm{PPM}$

$\square$ SIIICA $\geq 30 \mathrm{PPM}$ 


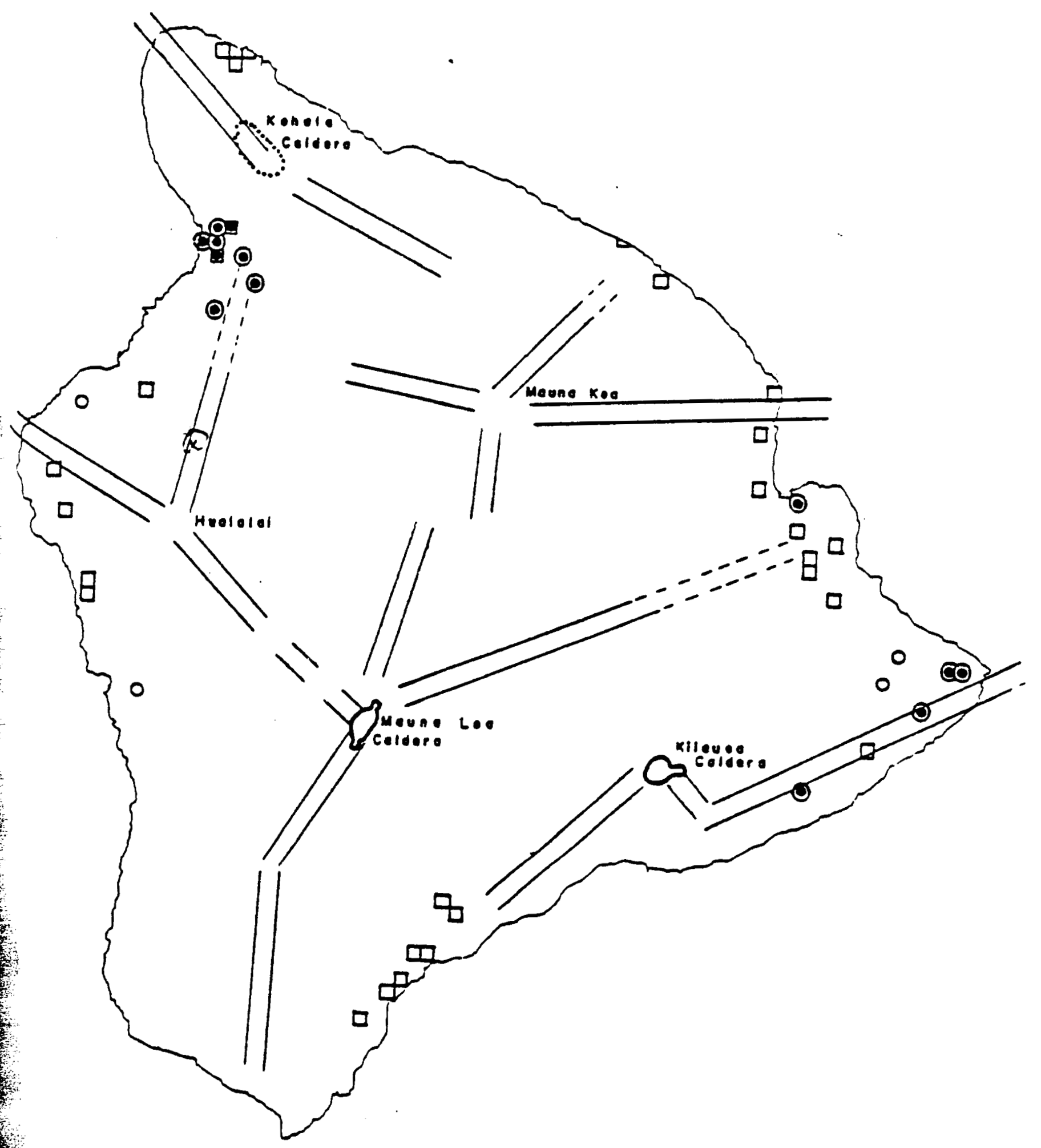

Figure A. Hawaii Structure 


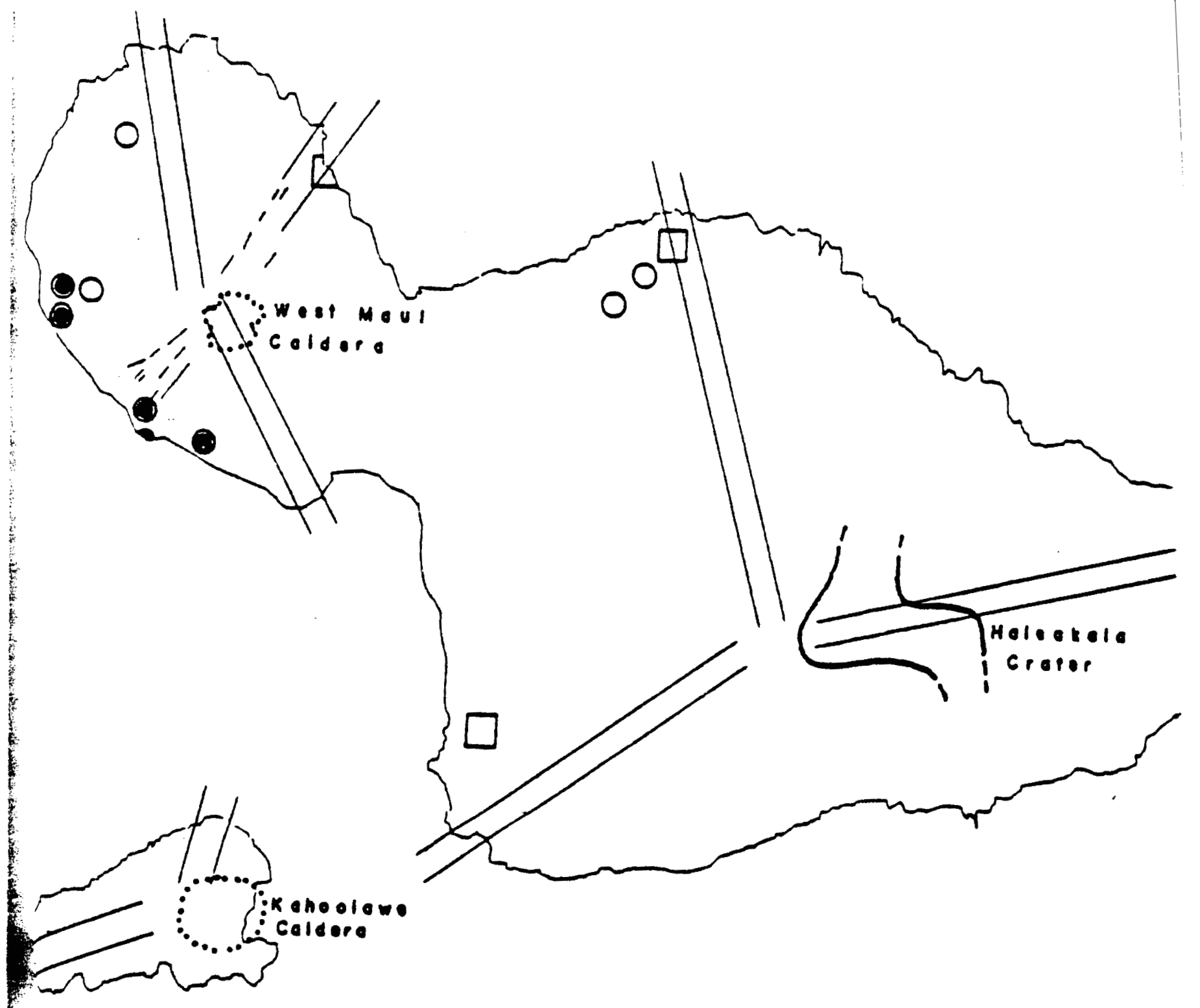

Figure B. Maui Structure 


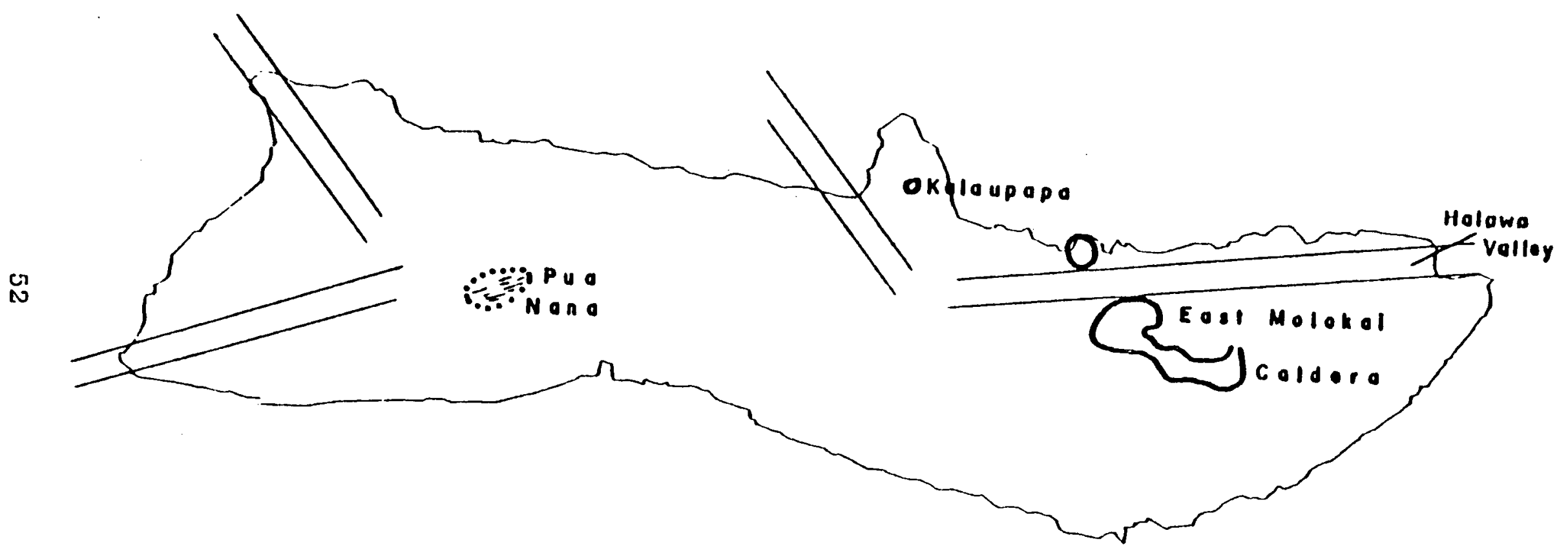

Figure C. Molokai Structure 


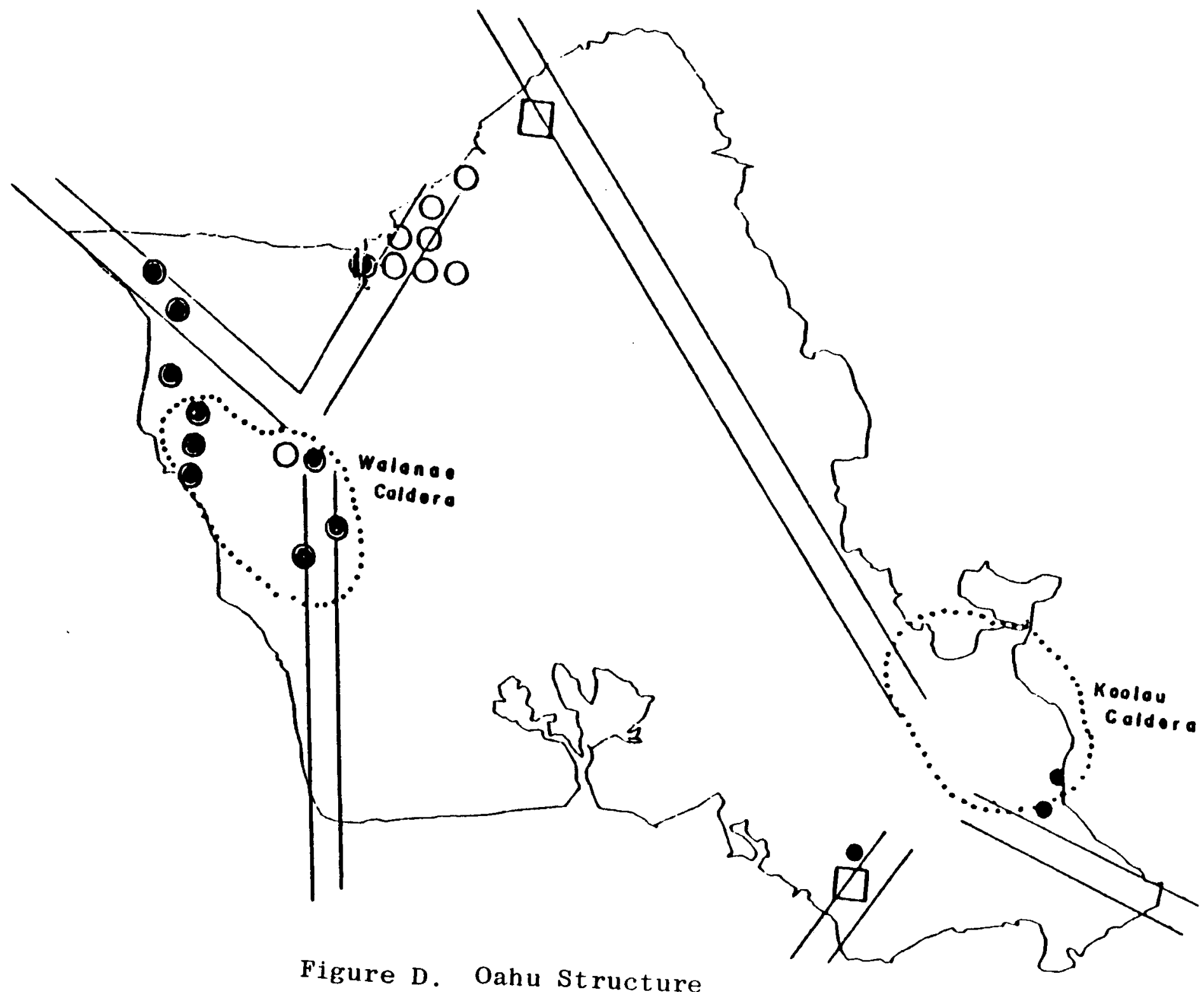




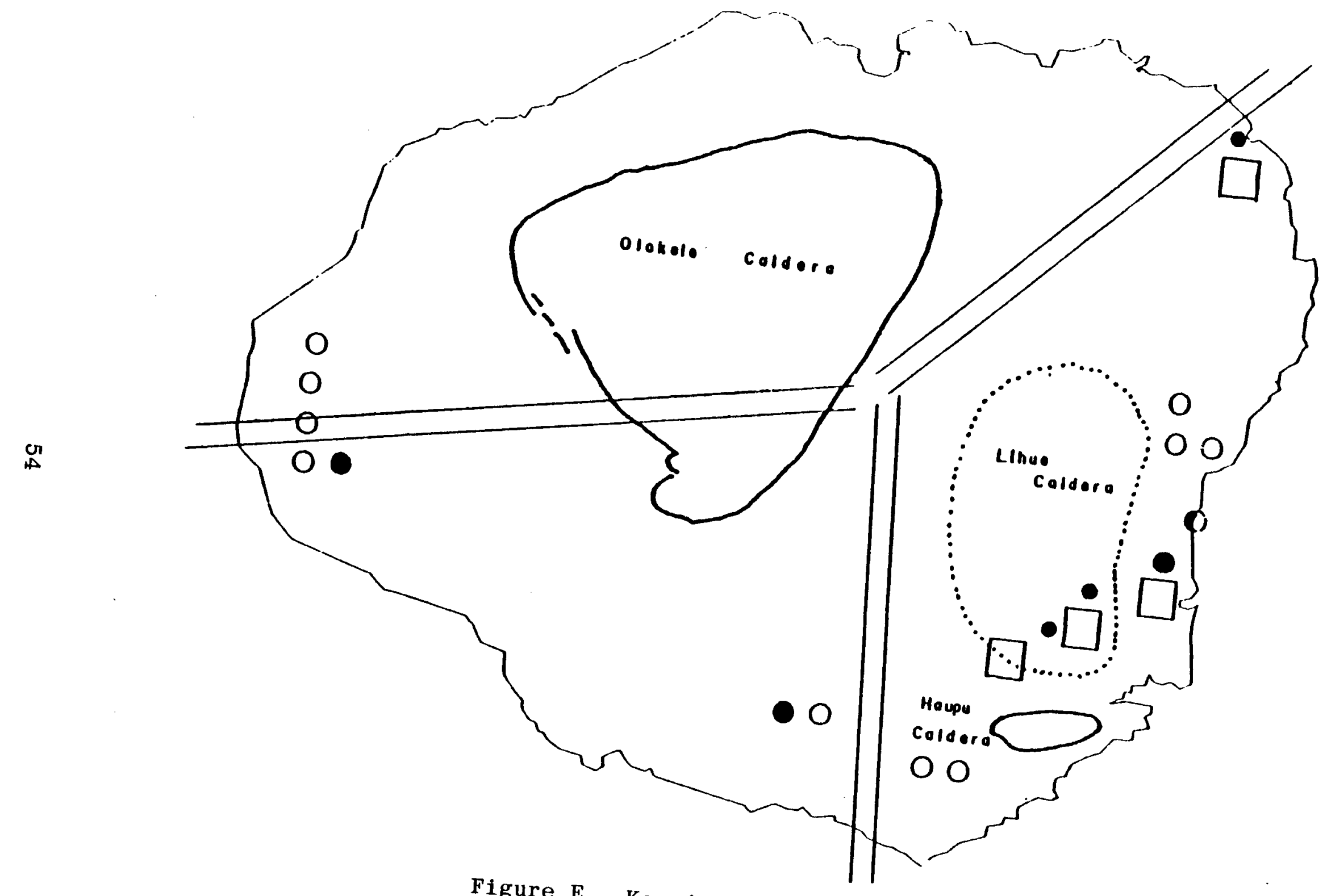

Figure E. Kauai structure 
APPENDIX B

Potential Users and Resources In the Hawaiian Islands

Legend for Potential Users and Resources

Figure $F$

Potential Users and Resources for Hawaii

Figure G Potential Users and Resources for Maui

Figure H

Potential Users and Resources for Oho

Figure I

Potential Users and Resources for Kauai

55 
AAATENTAL GEOTHERMAL RESOURCES THAT MEET AA: CONFIDENCE CRITERIA

- EIECTRIC UTIIITY PLANT

* SUGAR MILI/ELECTRIC GENERATOR

$D$ LIGHT INDUSTRY AREA

口 HOSPITAL $100+$ BEDS

HOTEL CONDOMINIUM AREAS

- EXISTING AQUACULTURE SIGHTS

$\therefore$

$\therefore=$ MAJOR URBAN AREA, LOCAIIONS NOT DETAILED $\therefore=$

Legend for Potential Users and Resources for Figures $F$ through I 


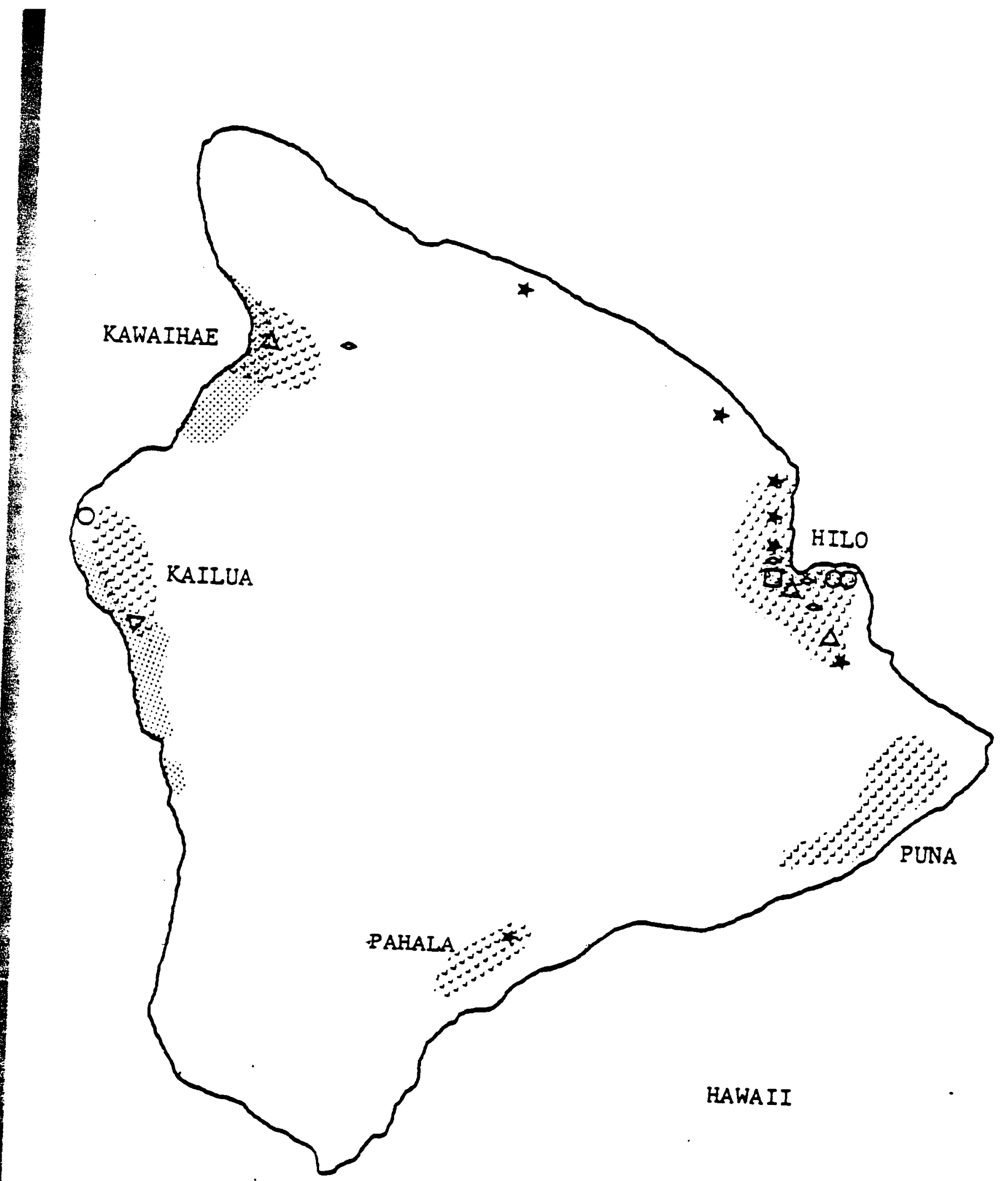

Figure F. Potential Users and Resources for Island of Hawaii 


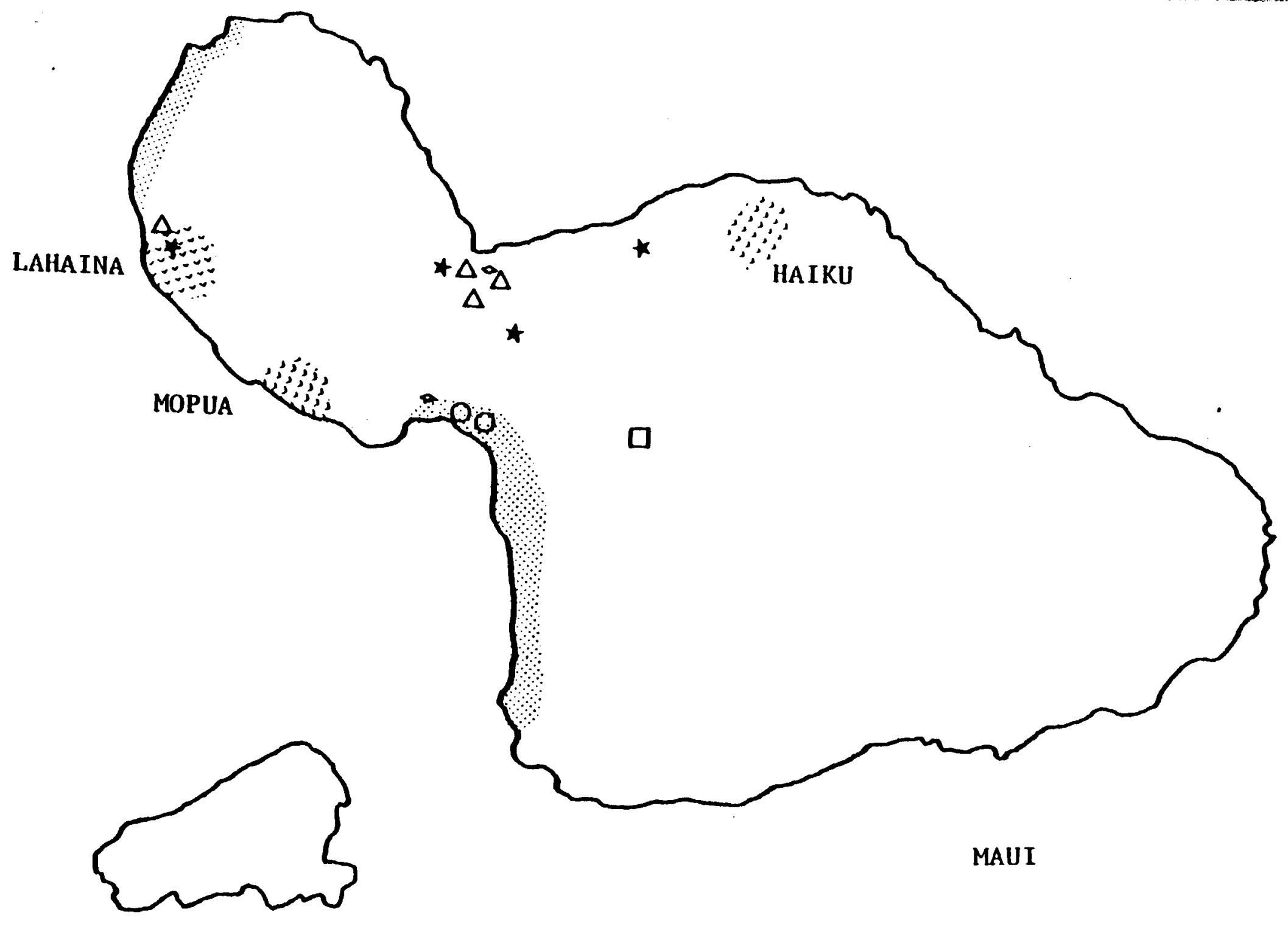

Figure G. Potential Users and Resources for the Island of Maui 


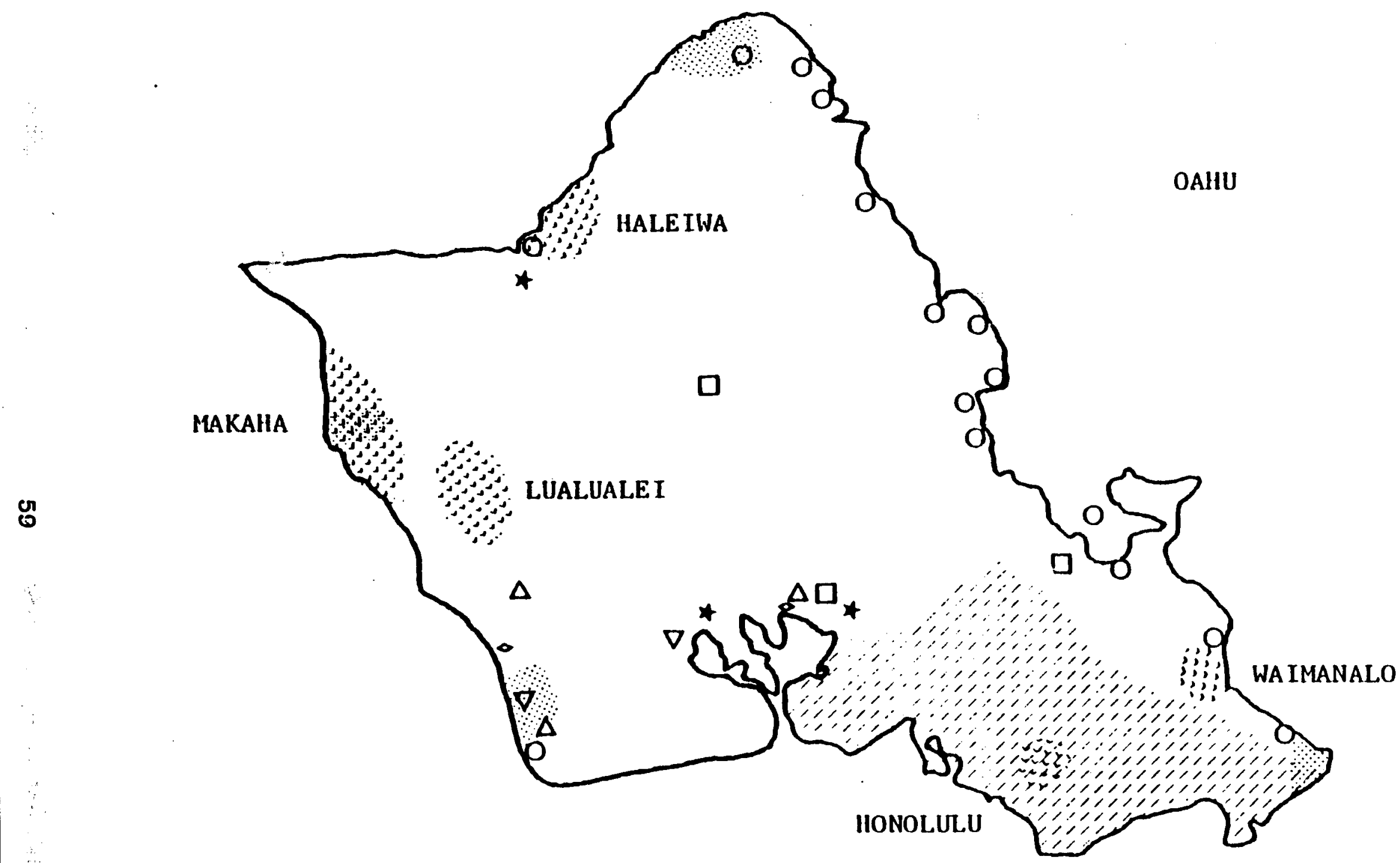

Figure H. Potential Users and Resources for Island of Oahu 